\title{
Synthesis of ruthenium vinylidene complexes with dppe ligand and their cyclopropenation reaction
}

\author{
Chao-Wan Chang, Pei-Chen Ting, Ying-Chih Lin *, Gene-Hsiang Lee, Yu Wang \\ Department of Chemistry, National Taiwan University, Taipei 106, Taiwan
}

Received 29 July 1997; received in revised form 15 September 1997

\begin{abstract}
A number of cationic ruthenium vinylidene complexes $[\mathrm{Ru}]=\mathrm{C}=\mathrm{C}(\mathrm{Ph}) \mathrm{CH}_{2} \mathrm{R}^{+} \quad\left([\mathrm{Ru}]=\left(\eta^{5}-\mathrm{C}_{5} \mathrm{H}_{5}\right)(\mathrm{dppe}) \mathrm{Ru}, \quad \mathrm{dppe}=\right.$ $\mathrm{Ph}_{2} \mathrm{PCH}_{2} \mathrm{CH}_{2} \mathrm{PPh}_{2}, \mathbf{5 a}, \mathrm{R}=\mathrm{CN} ; \mathbf{5 b}, \mathrm{R}=\mathrm{C}_{6} \mathrm{~F}_{5} ; \mathbf{5 c}, \mathrm{R}=\mathrm{Ph} ; \mathbf{5 d}, \mathrm{R}=p-\mathrm{C}_{6} \mathrm{H}_{4} \mathrm{CN} ; \mathbf{5 e}, \mathrm{R}=p-\mathrm{C}_{6} \mathrm{H}_{4} \mathrm{CF}_{3} ; \mathbf{5 f}, \mathrm{R}=1-\mathrm{C}_{10} \mathrm{H}_{7} ; \mathbf{5 g}$, $\mathrm{R}=\mathrm{CO}_{2} \mathrm{CH}_{3}$ ) are prepared from electrophilic addition of organic halides to the acetylide complex [Ru]-C $\equiv \mathrm{CPh}$ at the boiling point of $\mathrm{CHCl}_{3}$. Complex $\mathbf{5} \mathbf{g}^{\prime}$, prepared at room temperature, displays similar spectroscopic property as that of $\mathbf{5} \mathbf{g}$ but is easily hydrolyzed to give $[\mathrm{Ru}] \mathrm{COCH}_{2} \mathrm{Ph}(\mathbf{6})$. Cyclopropenation of the organic vinylidene moiety of $\mathbf{5 a}-\mathbf{5 f}$ is accomplished in acetone by deprotonation of $\mathbf{5}$ with $n-\mathrm{Bu}_{4} \mathrm{NOH}$ yielding the neutral cyclopropenyl complexes $[\mathrm{Ru}]-\mathrm{C}=\mathrm{C}(\mathrm{Ph}) \mathrm{CHR}\left(\mathbf{7 a}, \mathrm{R}=\mathrm{CN} ; \mathbf{7 b}, \mathrm{R}=\mathrm{C}{ }_{6} \mathrm{~F}_{5} ; \mathbf{7 c}, \mathrm{R}=\mathrm{Ph} ; \mathbf{7 d}, \mathrm{R}=p\right.$ $\mathrm{C}_{6} \mathrm{H}_{4} \mathrm{CN} ; 7 \mathbf{e}, \mathrm{R}=p-\mathrm{C}_{6} \mathrm{H}_{4} \mathrm{CF}_{3} ; \mathbf{7 f}, \mathrm{R}=1-{ }_{10} \mathrm{H}_{7}$ ). Protonation of $\mathbf{7 b}-\mathbf{7 f}$ regenerates the corresponding vinylidene complexes. In the presence of allyl iodide, opening of the three-membered ring of $\mathbf{7 a}$, followed by a subsequent oxidative coupling reaction, gives a dimeric dicationic product $\{[\mathrm{Ru}]=\mathrm{C}=\mathrm{C}(\mathrm{Ph})-\mathrm{CHCN}\}_{2}^{+2}(\mathbf{9 a})$. In the processes of preparing the starting material $\mathrm{Cp}(\mathrm{dppe}) \mathrm{RuCl}$ for the acethylide complex, two dppe complexes $\mathrm{Ru}(\mathrm{dppe})_{2} \mathrm{Cl}_{2}(\mathbf{2})$ and $[\mathrm{Cp}(\mathrm{dppe}) \mathrm{RuCl}]_{2}(\mathbf{3})$ are isolated. Molecular structures of complexes $\mathbf{2}, \mathbf{3}, \mathbf{6}$, and $\mathbf{7 b}$ have been confirmed by X-ray diffraction analysis. (C) 1998 Elsevier Science S.A.
\end{abstract}

Keywords: Organic halides; Allyl iodide; Oxidative coupling reaction

\section{Introduction}

During the course of investigations into ruthenium vinylidene chemistry, we previously reported the formation of several interesting neutral cycloropenyl complexes [1]. For example, $\mathrm{Cp}\left(\mathrm{PPh}_{3}\right)_{2}$ $\mathrm{Ru}=\mathrm{C}=\mathrm{C}(\mathrm{Ph}) \mathrm{CH}_{2} \mathrm{CN}^{+}$in acetone was found to undergo deprotonation to afford the yellow crystalline cyclopropenyl complex $\mathrm{Cp}\left(\mathrm{PPh}_{3}\right)_{2} \mathrm{Ru}-\mathrm{C}=\mathrm{C}(\mathrm{Ph}) \mathrm{CHCN}$. The cationic charge along with the electron-withdrawing $\mathrm{CN}$ group appending to the vinylidene ligand make the protons at the $\gamma$-carbon acidic enough for facile deprotonation. This reaction generates a racemic mixture of the products with an asymmetric carbon at the three-membered ring. To elaborate the breadth of such a system, we set to study the ruthenium complex with the bidentate dppe ligand. Herein, we report results on this

\footnotetext{
${ }^{*}$ Corresponding author.
}

system. In addition, the process of preparing the starting material, two by-products were isolated and the structure determination is also described.

\section{Results and discussion}

\subsection{Preparation of metal dppe complex}

Treatment of $\mathrm{Cp}\left(\mathrm{PPh}_{3}\right)_{2} \mathrm{RuCl}$ with dppe in benzene affords the light yellow product $\mathrm{Cp}(\mathrm{dppe}) \mathrm{RuCl}$ (1) in ca. $70 \%$ yield [2,3]. Complex $\mathbf{1}$ is soluble in benzene. In addition to $\mathbf{1}$, some by-products are isolated as orangeyellow precipitates from which two ruthenium chloride complexes $\mathrm{Ru}\left(\right.$ dppe ${ }_{2} \mathrm{Cl}_{2}$ (2) [4] and $\left[\mathrm{Cp}(\mu\right.$-dppe $) \mathrm{RuCl}_{2}$ (3) were separated by recrystallization from $\mathrm{CH}_{2} \mathrm{Cl}_{2} /$ hexane as yellow and red crystals, respectively Table 1 . The yield of $\mathbf{2}$ is about $20 \%$ and the yield of $\mathbf{3}$ is approximately $5 \%$. In the ${ }^{31} \mathrm{P}$ NMR spectrum of 2 in $\mathrm{CDCl}_{3}$ at room temperature, the singlet resonance at $\delta 45.75$ is assigned to the dppe ligand indicating high symmetry of the complex. Similarly in 


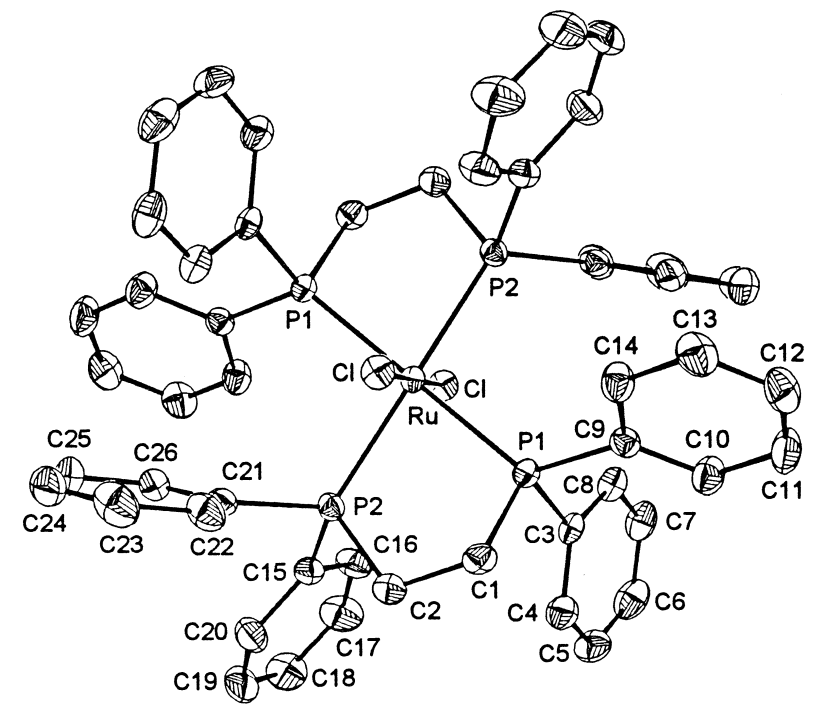

Fig. 1. An ORTEP drawing of (dppe) ${ }_{2} \mathrm{RuCl}_{2}$ (2) with thermal ellipsoids shown at the $50 \%$ probability level.

the ${ }^{31} \mathrm{P}$ NMR spectrum of $\mathbf{3}$, the singlet resonance at $\delta$ 37.05 is observed. Formation of complex $\mathbf{2}$ has been reported from the reaction of $\mathrm{RuCl}_{3} \cdot x \mathrm{H}_{2} \mathrm{O}$ with dppe however the structure has not been determined. Therefore, we carried out structure determination of $\mathbf{2}$ and $\mathbf{3}$ by single-crystal X-ray diffraction analysis and ORTEP drawings of $\mathbf{2}$ and $\mathbf{3}$ are shown in Fig. 1 and Fig. 2, respectively. Both complexes contain center of symmetry. In 2, which contains no Cp ligand, the two bidentate dppe ligands and the two chloro ligands form a pseudo octahedral geometry around the ruthenium metal center and the $\mathrm{Ru}-\mathrm{P}$ distances $(2.356(1), 2.381(1) \AA)$ are

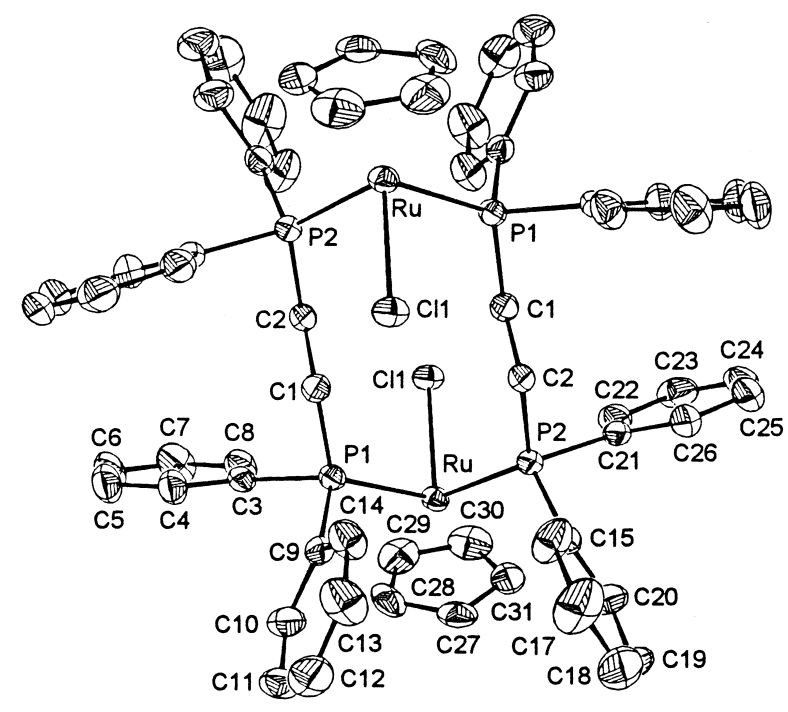

Fig. 2. An ORTEP drawing of $\mathrm{Cp}_{2}(\mathrm{dppe})_{2} \mathrm{Ru}_{2} \mathrm{Cl}_{2}$ (3) with thermal ellipsoids shown at the $50 \%$ probability level.

slightly longer than the corresponding ones (2.311(2), 2.326(2) $\AA$ ) in dinuclear complex 3 containing a Cp ligand in each metal center. And the $\mathrm{Ru}-\mathrm{Cl}$ distance $(2.433(1) \AA)$ of 2 Table 2 is slightly shorter than the corresponding one $(2.506(2) \AA)$ in $\mathbf{3}$ Table 3 . The two dppe ligands in 3 bridge two metal centers with the $\mathrm{P}(1)-\mathrm{C}(1)-\mathrm{C}(2)$ and $\mathrm{P}(2)-\mathrm{C}(2)-\mathrm{C}(1)$ angles (115.9(5) and $\left.110.2(5)^{\circ}\right)$ approximately the same as that (112.3(3) and $\left.114.2(3)^{\circ}\right)$ of the bidentate one in $\mathbf{2}$. The acetylide complex $[\mathrm{Ru}]-\mathrm{C} \equiv \mathrm{CPh}(4)$ is prepared by the reaction of 1 with $\mathrm{PhC} \equiv \mathrm{CH}$ in high yield and display identical spectroscopic properties as that in the literature [5].

Table 1

Crystal and intensity collection data for (dppe) $\mathrm{RuCl}_{2} \quad \mathbf{2}, \quad \mathrm{Cp}_{2}(\mathrm{dppe})_{2} \mathrm{Ru}_{2} \mathrm{Cl}_{2}, \quad \mathbf{3}, \quad \mathrm{Cp}(\mathrm{dppe}) \mathrm{Ru}\left(\mathrm{COCH}{ }_{2} \mathrm{C}_{6} \mathrm{H}_{5}\right), \quad \mathbf{6}$ and $\mathrm{Cp}(\mathrm{dppe}) \mathrm{Ru}\left[\stackrel{\mathrm{C}=\mathrm{C}\left(\mathrm{C}_{6} \mathrm{H}_{5}\right) \mathrm{C}}{\mathrm{H}}\left(\mathrm{C}_{6} \mathrm{~F}_{5}\right)\right], 7 \mathbf{b}$

\begin{tabular}{|c|c|c|c|c|}
\hline $\begin{array}{l}\text { Molecular formula } \\
\text { Molecular weight }\end{array}$ & $\begin{array}{l}\mathrm{C}_{60} \mathrm{H}_{64} \mathrm{O}_{2} \mathrm{P}_{4} \mathrm{Cl}_{2} \mathrm{Ru}, \mathbf{2} \\
1113.02\end{array}$ & $\begin{array}{l}\mathrm{C}_{32} \mathrm{H}_{30} \mathrm{P}_{2} \mathrm{Cl}_{4} \mathrm{Ru}, \mathbf{3} \\
719.41\end{array}$ & $\begin{array}{l}\mathrm{C}_{45} \mathrm{H}_{48} \mathrm{O}_{3} \mathrm{P}_{3} \mathrm{~F}_{6} \mathrm{Ru}, \mathbf{6} \\
944.84\end{array}$ & $\begin{array}{l}\mathrm{C}_{46} \mathrm{H}_{35} \mathrm{P}_{2} \mathrm{~F}_{5} \mathrm{Ru}, 7 \mathrm{~b} \\
845.78\end{array}$ \\
\hline$a(\AA)$ & $11.371(3)$ & $13.190(2)$ & $11.777(3)$ & $12.094(7)$ \\
\hline$c(\AA)$ & $17.232(3)$ & $14.507(5)$ & $15.433(5)$ & $13.050(3)$ \\
\hline$\alpha\left(^{\circ}\right)$ & - & - & - & $94.19(2)$ \\
\hline$\beta\left(^{\circ}\right)$ & $96.02(2)$ & $102.08(2)$ & $105.87(3)$ & $91.33(3)$ \\
\hline$V\left(\AA^{3}\right)$ & $2622.5(9)$ & $3211.9(15)$ & $4339.9(19)$ & $1962.8(13)$ \\
\hline$Z$ & 2 & 4 & 4 & 2 \\
\hline Crystal dimension $\left(\mathrm{mm}^{3}\right)$ & $0.20 \times 0.30 \times 0.50$ & $0.32 \times 0.40 \times 0.50$ & $0.10 \times 0.50 \times 0.50$ & $0.10 \times 0.15 \times 0.30$ \\
\hline Radiation & \multicolumn{4}{|c|}{ Mo K $\alpha \lambda=0.7093 \AA$} \\
\hline $2 \theta$ range & $2^{\circ}-50^{\circ}$ & $2^{\circ}-50^{\circ}$ & $2^{\circ}-50^{\circ}$ & $2^{\circ}-45^{\circ}$ \\
\hline Scan type & \multicolumn{4}{|c|}{$\theta / 2 \theta$} \\
\hline
\end{tabular}


Table 2

Selected interatomic distances $(\AA)$ and bond angles $\left(^{\circ}\right)$ of (dppe) ${ }_{2} \mathrm{RuCl}_{2}, 2$

\begin{tabular}{lllr}
\hline $\mathrm{Ru}-\mathrm{Cl}$ & $2.4325(12)$ & $\mathrm{P}(1)-\mathrm{C}(9)$ & $1.836(5)$ \\
$\mathrm{Ru}-\mathrm{C}(1)$ & $2.3563(13)$ & $\mathrm{P}(2)-\mathrm{C}(2)$ & $1.850(5)$ \\
$\mathrm{Ru}-\mathrm{P}(2)$ & $2.3811(13)$ & $\mathrm{P}(2)-\mathrm{C}(15)$ & $1.845(5)$ \\
$\mathrm{P}(1)-\mathrm{C}(1)$ & $1.843(5)$ & $\mathrm{P}(2)-\mathrm{C}(21)$ & $1.841(5)$ \\
$\mathrm{P}(1)-\mathrm{C}(3)$ & $1.823(5)$ & $\mathrm{C}(1)-\mathrm{C}(2)$ & $1.529(7)$ \\
$\mathrm{Cl}-\mathrm{Ru}-\mathrm{P}(1)$ & $85.81(4)$ & $\mathrm{P}(1)-\mathrm{Ru}-\mathrm{P}(2)$ & $81.62(5)$ \\
$\mathrm{Cl}-\mathrm{Ru}-\mathrm{P}(1) \mathrm{a}$ & $94.19(4)$ & $\mathrm{P}(1)-\mathrm{Ru}-\mathrm{P}(2) \mathrm{a}$ & $98.38(5)$ \\
$\mathrm{Cl}-\mathrm{Ru}-\mathrm{P}(2)$ & $81.40(4)$ & $\mathrm{P}(1)-\mathrm{C}(1)-\mathrm{C}(2)$ & $112.3(3)$ \\
$\mathrm{Cl}-\mathrm{Ru}-\mathrm{P}(2) \mathrm{a}$ & $98.60(4)$ & $\mathrm{P}(2)-\mathrm{C}(2)-\mathrm{C}(1)$ & $114.2(3)$ \\
\hline
\end{tabular}

\subsection{Preparation of vinylidene complexes}

Treatment of 4 with $\mathrm{ICH}_{2} \mathrm{CN}$ at refluxing temperature of $\mathrm{CHCl}_{3}$ affords the cationic vinylidene complex $[\mathrm{Ru}]=\mathrm{C}=\mathrm{C}(\mathrm{Ph}) \mathrm{CH}_{2} \mathrm{CN}^{+} \mathrm{I}^{-}(\mathbf{5 a})$ in $83 \%$ yield. In the presence of excess $\mathrm{NH}_{4} \mathrm{PF}_{6}$, the counter anion is replaced by $\mathrm{PF}_{6}^{-}$. Unlike other vinylidene complexes which are normally prepared by treatment of an acetylide complex with primary organic halide at room temperature for $\mathbf{1} \mathrm{d}$, complex $\mathbf{5 a}$ is prepared by heating the chloroform solution of $\mathbf{4}$ and primary alkyl halide to reflux for ca. $10 \mathrm{~h}$. The reaction at room temperature also gives the product with the same spectroscopic data but such a product is relatively less stable. Similarly, preparation of other vinylidene complexes $[\mathrm{Ru}]=\mathrm{C}=\mathrm{C}(\mathrm{Ph}) \mathrm{CH}_{2} \mathrm{R}^{+}\left(\mathbf{5 b}, \mathrm{R}=\mathrm{C}_{6} \mathrm{~F}_{5} ; \mathbf{5 c}, \mathrm{R}=\mathrm{Ph} ; \mathbf{5 d}\right.$, $\mathrm{R}=p-\mathrm{C}_{6} \mathrm{H}_{4} \mathrm{CN} ; \mathbf{5 e}, \mathrm{R}=p-\mathrm{C}_{6} \mathrm{H}_{4} \mathrm{CF}_{3} ; \mathbf{5 f}, \mathrm{R}=1-\mathrm{C}_{10} \mathrm{H}_{7}$; $\mathbf{5 g}, \mathrm{R}=\mathrm{COOCH}_{3}$ ) have been accomplished by reacting 4 with the corresponding halides at refluxing temperature of $\mathrm{CHCl}_{3}$ all with high yields. Interestingly, 5a is soluble in acetone and insoluble in $\mathrm{CH}_{3} \mathrm{CN}, \mathrm{CHCl}_{3}$ and $\mathrm{CH}_{2} \mathrm{Cl}_{2}$. Complexes $\mathbf{5 b} \mathbf{- 5 g}$ are all soluble in polar solvent such as $\mathrm{CHCl}_{3}, \mathrm{CH}_{2} \mathrm{Cl}_{2}, \mathrm{MeOH}$ and $\mathrm{CH}_{3} \mathrm{CN}$ but insoluble in acetone, ether and hexane. All 5a-5g prepared at higher temperature are quite stable even in solution. They display pink to orange color in their solid state. The characteristic spectroscopic data of these vinylidene complexes consist of strongly deshielded $\mathrm{C}_{\alpha}$ resonance as a triplet at $\delta 340 \pm 5$ in the ${ }^{13} \mathrm{C} \mathrm{NMR}$ spectrum and a singlet ${ }^{31} \mathrm{P}$ NMR resonance normally at around $\delta 77 \pm 1$ in $\mathrm{CDCl}_{3}$ at room temperature, which is due to the fluxional behavior of the vinylidene ligand $[6,7]$.

The newly formed carbon-carbon bond of the vinyli-

Table 3

Selected interatomic distances $(\AA)$ and bond angles $\left(^{\circ}\right)$ of $\mathrm{Cp}_{2}(\mathrm{dppe})_{2} \mathrm{Ru}_{2} \mathrm{Cl}_{2}, 3$

\begin{tabular}{llll}
\hline $\mathrm{Ru}-\mathrm{P}(1)$ & $2.3105(20)$ & $\mathrm{Ru}-\mathrm{Cl}(1)$ & $2.5060(20)$ \\
$\mathrm{Ru}-\mathrm{P}(2)$ & $2.3263(20)$ & $\mathrm{C}(1)-\mathrm{C}(2) \mathrm{a}$ & $1.513(10)$ \\
$\mathrm{P}(1)-\mathrm{Ru}-\mathrm{P}(2)$ & $96.99(7)$ & $\mathrm{P}(1)-\mathrm{C}(1)-\mathrm{C}(2) \mathrm{a}$ & $115.9(5)$ \\
$\mathrm{P}(1)-\mathrm{Ru}-\mathrm{Cl}(1)$ & $93.93(7)$ & $\mathrm{P}(2)-\mathrm{C}(2)-\mathrm{C}(1) \mathrm{a}$ & $110.2(5)$ \\
$\mathrm{P}(2)-\mathrm{Ru}-\mathrm{Cl}(1)$ & $93.95(6)$ & & \\
\hline
\end{tabular}

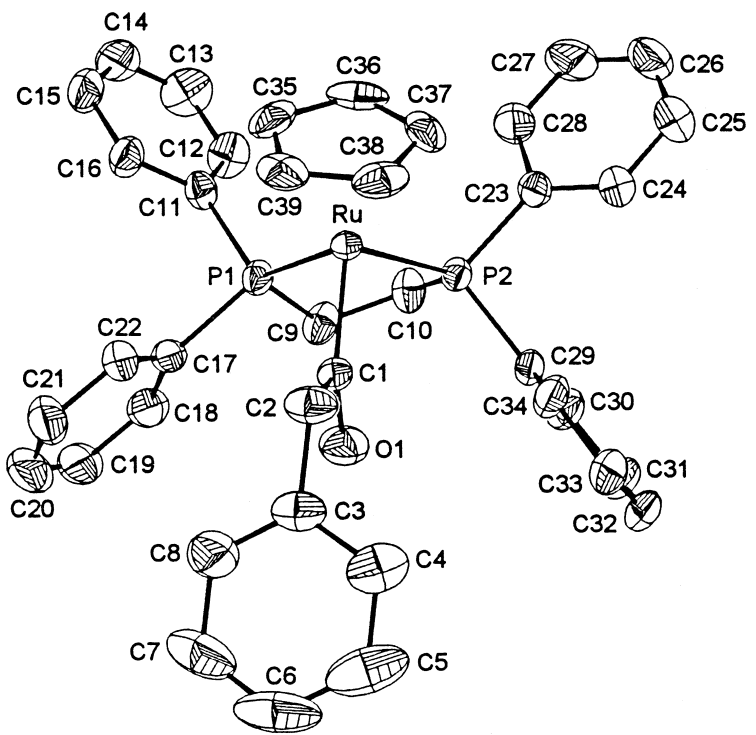

Fig. 3. An ORTEP drawing of $\mathrm{Cp}(\mathrm{dppe}) \mathrm{Ru}\left(\mathrm{COCH}_{2} \mathrm{C}_{6} \mathrm{H}_{5}\right)$ (6) with thermal ellipsoids shown at the $50 \%$ probability level.

dene complexes, prepared by carrying out the reaction at room temperature, is easily cleaved in the presence of acid. In addition, the hexafluorophosphate salt $\mathrm{NH}_{4} \mathrm{PF}_{6}$ used for the preparation is easily converted to $\mathrm{HPF}_{6}$. Thus complex $5 \mathbf{g}^{\prime}$ with $\mathrm{PF}_{6}^{-}$counter anion prepared at room temperature is unstable when dissolved in $\mathrm{CH}_{2} \mathrm{Cl}_{2}$ /hexane solution. It decomposes to give the acyl complex $[\mathrm{Ru}] \mathrm{C}(\mathrm{O}) \mathrm{CH}_{2} \mathrm{Ph}(\mathbf{6})$. With $\mathrm{Br}^{-}$anion, $5 \mathbf{g}^{\prime}$ is stable for a period of $2 \mathrm{~d}$ and then decomposes to some unidentified products. Complexes $\mathbf{5 a}^{\prime}$ and $\mathbf{5 b}^{\prime}$ both with $\mathrm{PF}_{6}^{-}$anion are prepared at room temperature, they also decompose to give $\mathbf{6}$ but with the halide as the counter anion they are relatively more stable. It seems that the presence of $\mathrm{HPF}_{6}$ is required for the formation of 6 .

In the ${ }^{31} \mathrm{P}$ NMR spectrum of $\mathbf{6}$, a singlet resonance at $\delta 91.10$ is observed. The structure of $\mathbf{6}$ is determined by a single crystal X-ray diffraction analysis. An ORTEP drawing is shown in Fig. 3. The acyl ligand is clearly seen with the acyl plane ( $\mathrm{Ru}, \mathrm{C} 1, \mathrm{C} 2, \mathrm{O} 1)$ bisecting the $\mathrm{P} 1-\mathrm{Ru}-\mathrm{P} 2$ angle Table 4 . Such a transformation has been observed in other vinylidene complexes [8]. Pre-

Table 4

Selected interatomic distances $(\AA)$ and bond angles $\left(^{\circ}\right)$ of $\mathrm{Cp}($ dppe $) \mathrm{Ru}\left(\mathrm{COCH}_{2} \mathrm{C}_{6} \mathrm{H}_{5}\right), 6$

\begin{tabular}{lcll}
\hline $\mathrm{Ru}-\mathrm{P}(1)$ & $2.2655(17)$ & $\mathrm{O}(1)-\mathrm{C}(1)$ & $1.328(7)$ \\
$\mathrm{Ru}-\mathrm{P}(2)$ & $2.2713(17)$ & $\mathrm{C}(2)-\mathrm{C}(3)$ & $1.509(10)$ \\
$\mathrm{Ru}-\mathrm{C}(1)$ & $1.992(6)$ & $\mathrm{C}(9)-\mathrm{C}(10)$ & $1.496(10)$ \\
$\mathrm{C}(1)-\mathrm{C}(2)$ & $1.530(10)$ & & \\
$\mathrm{P}(1)-\mathrm{Ru}-\mathrm{P}(2)$ & $84.99(6)$ & $\mathrm{O}(1)-\mathrm{C}(1)-\mathrm{C}(2)$ & $110.6(5)$ \\
$\mathrm{P}(1)-\mathrm{Ru}-\mathrm{C}(1)$ & $88.45(17)$ & $\mathrm{C}(1)-\mathrm{C}(2)-\mathrm{C}(3)$ & $117.3(5)$ \\
$\mathrm{P}(2)-\mathrm{Ru}-\mathrm{C}(1)$ & $93.83(17)$ & $\mathrm{P}(1)-\mathrm{C}(9)-\mathrm{C}(10)$ & $111.7(5)$ \\
$\mathrm{Ru}-\mathrm{C}(1)-\mathrm{O}(1)$ & $127.9(5)$ & $\mathrm{P}(2)-\mathrm{C}(10)-\mathrm{C}(9)$ & $111.8(5)$ \\
$\mathrm{Ru}-\mathrm{C}(1)-\mathrm{C}(2)$ & $121.5(4)$ & & \\
\hline
\end{tabular}


sumably, protonation at $\mathrm{C}_{\beta}$ of the acetylide complex followed by hydroxy-attack at the $\mathrm{C}_{\alpha}$ led to the product. If complex $\mathbf{5}$ is prepared by thermolysis in $\mathrm{CHCl}_{3}$ solution, no such transformation is observed. For example, treatment of $\mathbf{5 g}$, prepared at refluxing temperature of $\mathrm{CHCl}_{3}$, with $\mathrm{CH}_{3} \mathrm{COOH}, \mathrm{H}_{2} \mathrm{O}$ or $\mathrm{NH}_{4} \mathrm{PF}_{6}$ for 3 days results in recovery of the starting material. The vinylidene complexes $\mathbf{5}$ and $\mathbf{5}^{\prime}$ prepared at room temperature and at $55^{\circ} \mathrm{C}$ display similar spectroscopic features but their reactivities are quite different.

\subsection{Deprotonation / cyclopropenation of vinylidene complexes}

Deprotonation of $5 \mathbf{a}$ by $n-\mathrm{Bu}_{4} \mathrm{NOH}$ in acetone induces a cyclization reaction and yields the neutral cy-

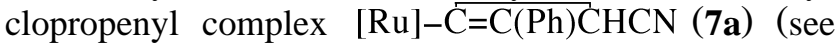
Scheme). No cyclopropenation reaction is observed in $\mathrm{CH}_{3} \mathrm{CN}$. The light orange-yellow crystalline product forms directly in the reaction mixture and can be obtained in analytically pure form by filtration. Complex 7a is stable and is soluble in $\mathrm{CH}_{2} \mathrm{Cl}_{2}, \mathrm{CHCl}_{3}$, and THF but insoluble in ether, $n$-hexane, $\mathrm{MeOH}$ and $\mathrm{CH}_{3} \mathrm{CN}$. In the ${ }^{1} \mathrm{H}$ NMR spectrum of $\mathbf{7 a}$, the resonance of the methyne proton of the three-membered ring appears at $\delta$ 2.13. The ${ }^{31} \mathrm{P}$ NMR spectrum of $7 \mathbf{a}$ displays two doublet resonances at $\delta 90.14$ and 88.47 with ${ }^{2} J_{\mathrm{P}-\mathrm{P}}=$ $24.3 \mathrm{~Hz}$ assignable to the two non-equivalent phosphorus atoms of the dppe ligand arising from the asymmetric cyclopropenyl ring.

The deprotonation/cyclopropenation process in acetone is a general reaction for a number of vinylidene complexes. Namely, the same reaction occurs for similar complexes $\mathbf{5 b}-\mathbf{5 f}$ giving cyclopropenyl complexes $[\mathrm{Ru}]-\mathrm{C}=\mathrm{C}(\mathrm{Ph}) \mathrm{C} H R,\left(\mathbf{7 b}, \mathrm{R}=\mathrm{C}_{6} \mathrm{~F}_{5} ; \mathbf{7 c}, \mathrm{R}=\mathrm{Ph} ; \mathbf{7 d}\right.$, $\mathrm{R}=p-\mathrm{C}_{6} \mathrm{H}_{4} \mathrm{CN} ; \quad$ 7e, $\quad \mathrm{R}=p-\mathrm{C}_{6} \mathrm{H}_{4} \mathrm{CF}_{3} ; \quad \mathbf{7 f}, \quad \mathrm{R}=1-$ $\mathrm{C}_{10} \mathrm{H}_{7}$ ), respectively. Spectroscopic data of complexes $\mathbf{7}$ are similar. The single crystals of $\mathbf{7 b}$ suitable for $\mathrm{X}$-ray diffraction analysis are obtained when the reaction is carried out at lower concentration. Complexes 7c-7f are not stable in solution. Presence of the pentafluorophenyl group in $\mathbf{7 b}$ exceptionally stabilizes the complex. Thus, complex $\mathbf{7 b}$ is stable in $\mathrm{CHCl}_{3}$, but other cyclopropenyl complexes decompose in $\mathrm{CHCl}_{3}$ within 10 h. Facile deprotonation of 5 by $n-\mathrm{Bu}_{4} \mathrm{NOH}$ indicates acidic nature of the methylene protons of $\mathbf{5 a}-\mathbf{5 f}$, which may be associated with the combined influence of the cationic character, the electron withdrawing substituent and the benzylic property of the vinylidene complexes. It also appears that the hybridization of the $\mathrm{C}_{\delta}$ atom should be $s p^{2}$ for the cyclopropenation reaction to occur. Complex $\mathbf{5 g}$ failed to yield the deprotonation product in the presence of $\mathrm{Bu}_{4} \mathrm{NOH}$. We previously observed formation of cyclopropenyl and furanyl products for the bistriphenylphosphine analogue of 5g. But with the dppe ligand, the starting material was recovered. Better donor ability of the dppe along with the ester group appending to the vinylidene ligand may make the methylene protons less acidic in $\mathbf{5 g}$ thus, deter the deprotonation process.

Synthesis of metal cyclopropenyl derivatives in which the metal bonds to $\mathrm{C}\left(s p^{3}\right)$ of the cyclopropene ring (in this case the three-membered ring can be viewed as an antiaromatic cyclopropenide ions) have been reported in the literature [9-13]. However, to our knowledge, only few example of such derivative in which the metal is bonded to the $\mathrm{C}\left(s p^{2}\right)$ of the three-membered ring has been reported [14]. A few structurally different transition metal cyclopropenylidene complexes, mostly prepared from dichlorocyclopropene [15-17] and a number of $\pi$-cyclopropene complexes [18-21] are also known. The acidity of the aliphatic protons on a coordinated dppe ligand in a cationic iron vinylidene complex [22] has been employed for inducing the intramolecular cyclization between the dppe and vinylidene ligand.

\subsection{Molecular structure of the Ru cyclopropenyl com- plex $7 \boldsymbol{b}$}

The molecular structure of $\mathbf{7 b}$ has been determined by X-ray diffraction study. An ORTEP drawing of $\mathbf{7 b}$ is shown in Fig. 4. The cyclopropenyl ring is clearly seen with the pentafluorophenyl group bound to the unique $s p^{3}$ carbon. The Ru-C(1) bond length of 2.009(10) $\AA$ Table 5 is typical for a $\mathrm{Ru}-\mathrm{C}\left(s p^{2}\right)$ single bond and the $\mathrm{C}(1)-\mathrm{C}(3)$ bond length of $1.310(14) \AA$ is a double bond, indicating coordination of the $s p^{2}$ carbon of the cyclopropenyl ligand. The bond angles $\mathrm{Ru}-\mathrm{C}(1)-\mathrm{C}(3)$ and $C(1)-C(3)-C(4)$ of $165.6(4)^{\circ}$ and $154.0(5)^{\circ}$, respectively, are both far greater than that of an idealized

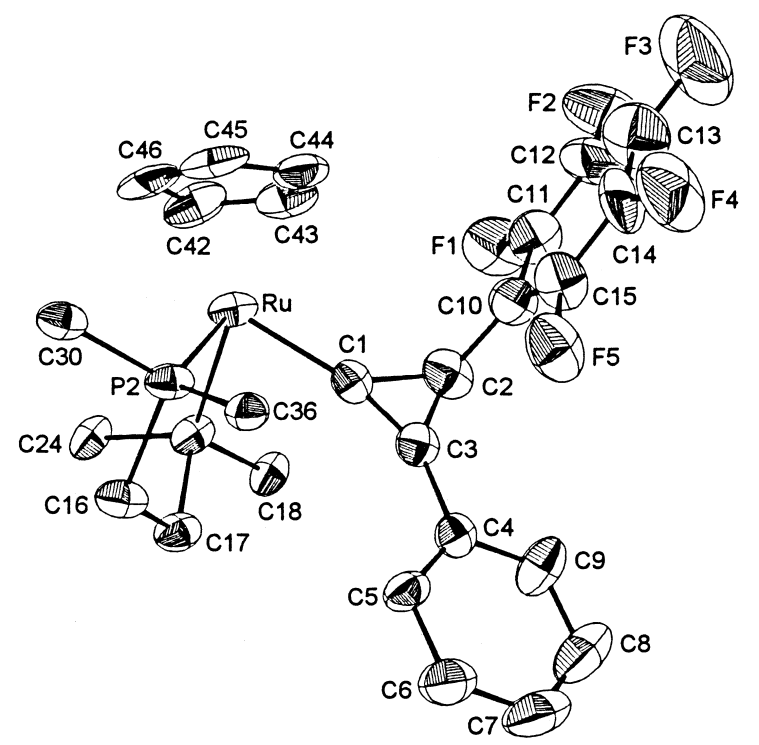

Fig. 4. An ORTEP drawing of $\mathrm{Cp}($ dppe $) \mathrm{Ru}-\mathrm{C}=\mathrm{C}\left(\mathrm{C}_{6} \mathrm{H}_{5}\right) \mathrm{CH}\left(\mathrm{C}_{6} \mathrm{~F}_{5}\right)$ (7b) (50\% thermal ellipsoids) with the phenyl groups on the dppe ligand eliminated for clarity. 
Table 5

Selected interatomic distances $(\AA)$ and bond angles $\left(^{\circ}\right)$ of $\mathrm{Cp}($ dppe $) \mathrm{Ru}\left[\mathrm{C}=\mathrm{C}(\mathrm{Ph}) \mathrm{CH}\left(\mathrm{C}_{6} \mathrm{~F}_{5}\right)\right], \mathbf{7 b}$

\begin{tabular}{lclc}
\hline $\mathrm{Ru}-\mathrm{P}(1)$ & $2.237(3)$ & $\mathrm{C}(1)-\mathrm{C}(3)$ & $1.310(14)$ \\
$\mathrm{Ru}-\mathrm{P}(2)$ & $2.231(3)$ & $\mathrm{C}(2)-\mathrm{C}(3)$ & $1.467(15)$ \\
$\mathrm{Ru}-\mathrm{C}(1)$ & $2.009(10)$ & $\mathrm{C}(2)-\mathrm{C}(10)$ & $1.453(16)$ \\
$\mathrm{C}(1)-\mathrm{C}(2)$ & $1.584(16)$ & $\mathrm{C}(3)-\mathrm{C}(4)$ & $1.463(14)$ \\
$\mathrm{C}(16)-\mathrm{C}(17)$ & $1.529(15)$ & & \\
$\mathrm{P}(1)-\mathrm{Ru}-\mathrm{P}(2)$ & $84.60(12)$ & $\mathrm{C}(1)-\mathrm{C}(2)-\mathrm{C}(10)$ & $119.7(10)$ \\
$\mathrm{P}(1)-\mathrm{Ru}-\mathrm{C}(1)$ & $81.0(3)$ & $\mathrm{C}(3)-\mathrm{C}(2)-\mathrm{C}(10)$ & $122.8(9)$ \\
$\mathrm{P}(2)-\mathrm{Ru}-\mathrm{C}(1)$ & $90.8(3)$ & $\mathrm{C}(1)-\mathrm{C}(3)-\mathrm{C}(2)$ & $69.3(8)$ \\
$\mathrm{Ru}-\mathrm{C}(1)-\mathrm{C}(2)$ & $133.9(7)$ & $\mathrm{C}(1)-\mathrm{C}(3)-\mathrm{C}(4)$ & $154.0(10)$ \\
$\mathrm{Ru}-\mathrm{C}(1)-\mathrm{C}(3)$ & $165.6(8)$ & $\mathrm{C}(2)-\mathrm{C}(3)-\mathrm{C}(4)$ & $136.5(10)$ \\
$\mathrm{C}(2)-\mathrm{C}(1)-\mathrm{C}(3)$ & $60.0(7)$ & $\mathrm{P}(2)-\mathrm{C}(16)-\mathrm{C}(17)$ & $110.5(7)$ \\
$\mathrm{C}(1)-\mathrm{C}(2)-\mathrm{C}(3)$ & $50.7(6)$ & $\mathrm{P}(1)-\mathrm{C}(17)-\mathrm{C}(16)$ & $107.5(6)$ \\
\hline
\end{tabular}

$\mathrm{C}\left(s p^{2}\right)$ hybridization. The $\mathrm{C}(1)-\mathrm{C}(2)$ and $\mathrm{C}(2)-\mathrm{C}(3)$ bond lengths of 1.58(2) and 1.47(2) $\AA$, respectively, are significantly different, conforming with the favorable cleavage of the $\mathrm{C}(1)-\mathrm{C}(2)$ bond described below. The phenyl group on the three-membered ring is approximately coplanar with the cyclopropene and lies far away from the $\mathrm{Cp}$.

\subsection{Electrophilic additions of ruthenium cyclopropenyl complexes 7}

Addition of $\mathrm{CF}_{3} \mathrm{COOH}$ at $-60^{\circ} \mathrm{C}$ to $7 \mathbf{a}$ regenerates 5a in quantitative NMR yield indicating basic character of the methyne carbon of the three-membered ring. But if the reaction is carried out at room temperature, in addition to 5a, an unidentified product is observed. This ring opening process by protonation is different from the acid induced demethoxylation of the iron cyclopropenyl complex [14]. Treatment of $\mathbf{7 b}$ with $\mathrm{HgCl}_{2}$ also affords the vinylidene product $\left\{[\mathrm{Ru}]=\mathrm{C}=\mathrm{C}(\mathrm{Ph}) \mathrm{CH}\left(\mathrm{C}_{6} \mathrm{~F}_{5}\right) \mathrm{HgCl}\right\}^{+}(\mathbf{8 b})$. In the ${ }^{1} \mathrm{H} \mathrm{NMR}$ spectrum of $\mathbf{8 b}$ in $\mathrm{CDCl}_{3}$, the resonance at $\delta 3.38$ is assigned to the methyne proton near the $\mathrm{HgCl}$ group. And in the ${ }^{31} \mathrm{P}$ NMR spectrum the two resonances at $\delta$ 78.59 and 78.10 with $J_{\mathrm{P}-\mathrm{P}}=18.2 \mathrm{~Hz}$ assignable to the dppe are due to the asymmetric center at the $\mathrm{C}_{\gamma}$. In the FAB MS spectrum, the parent peak for the cation is observed at $m / z=1083.1$. The vinylidene complexes $5 \mathbf{a}$ and $\mathbf{8 b}$ are formed by selective cleavage of the single bond of the cyclopropenyl ring near the metal center. This selectivity is similar to that reported for the unsymmetrical organic cyclopropenes where the single bond with a methyl substituent is cleaved [23]. Attempts to carry out cyclopropenation of $\mathbf{8 b}$ by using $n-\mathrm{Bu}_{4} \mathrm{NOH}$, $n-\mathrm{Bu}_{4} \mathrm{NF}$ and $\mathrm{DBU}$ result in cleavage of the $\mathrm{C}-\mathrm{Hg}$ bond yielding $\mathbf{5 b}$.
2.6. Oxidative coupling reactions of metal cyclopropenyl complex

Treatment of 7a with 20 fold excess of allyl iodide affords the dimeric dicationic vinylidene complex $\left\{[\mathrm{Ru}]=\mathrm{C}=\mathrm{C}(\mathrm{Ph}) \mathrm{CHCN}_{2}^{+2}\right.$ (9a). Other organic iodides such as methyl iodide, ethyl iodide and iodobenzene does not generate the coupling product. No similar product was obtained in the reactions of $\mathbf{7 b}$ or $\mathbf{7} \mathbf{c}$ with allyl iodide. Complex 9a is insoluble in most of the organic solvents and only sparingly soluble in DMSO wherein it forms an orange colored solution. The mass spectrum of 9a is consistent with the formulation $\{[\mathrm{Ru}]=\mathrm{C}=\mathrm{C}(\mathrm{Ph}) \mathrm{CHCN}\}_{2} \mathrm{I}^{+}$. In the ${ }^{31} \mathrm{P}$ NMR spectrum of $9 \mathrm{a}$, the chemical shift of the resonances at $\delta 76.34$ and 75.28 is comparable to that observed for $\mathbf{5 a}$.

Apparently a cationic ruthenium vinylidene radical $[24,25]$ may be formed at the initial stage of the reaction of 7a with $\mathrm{C}_{3} \mathrm{H}_{5} \mathrm{I}$. Oxidative coupling of such a radical satisfactorily accounts for the formation of the product 9a. Previous example of oxidative carbon-carbon coupling of the cationic iron vinylidene complex $[\mathrm{Cp}(\mathrm{dppe}) \mathrm{Fe}=\mathrm{C}=\mathrm{CHMe}]^{+}$leading to the formation of a dimer $[\mathrm{Cp}(\mathrm{dppe}) \mathrm{Fe}=\mathrm{C}=\mathrm{CMe}]_{2}^{+2}$ has been reported [26], whereas a very similar coupling [27] reaction has been attributed to the presence of 17 electron species confirmed by ESR [28], The coupling of allyl radical resulting in formation of bicyclopropyl molecule [29] and radical annulations of allyl iodomalononitriles [30] have been reported in the literature. Unsubstituted vinylidene complex $\mathrm{Cp}\left(\mathrm{PPh}_{3}\right)_{2} \mathrm{Ru}=\mathrm{C}=\mathrm{CH}_{2}$ also undergoes oxidative coupling in the presence of $\mathrm{MeI}$ and generates a similar dimer [31]. There are also few examples of metal acetylide couplings [32-34]. Possible role of azavinylidene [35] in the conversion of nitriles to diimido-bridged dimer in tantalum and niobium complexes [36-38] has been recently addressed. These examples are, nevertheless, different from what is observed in 7a, namely in our system the oxidative coupling at $\mathrm{C}_{\gamma}$ results in formation of a $\mathrm{C}_{6}$ bridge between the two $\mathrm{Ru}$ metal centers. Unlike the phosphine analogue [1], the dppe dimer 9a does not undergo deprotonation to yield the bis(cyclopropenyl) complex.

\subsection{Conclusion}

The preparation of neutral $\mathrm{Ru}$ cyclopropenyl complexes containing dppe ligand has been accomplished by deprotonation of a $\mathrm{CH}$ or $\mathrm{CH}_{2}$ unit at $\mathrm{C}_{\gamma}$ of the cationic vinylidene complexes in acetone. Preparation of complexes with various substituents such as $\mathrm{CN}, \mathrm{Ph}$ and 1-naphthyl groups at $\mathrm{CH}$ or $\mathrm{CH}_{2}$ renders this preparation a potentially versatile synthetic method. Protonation of the cyclization products regenerates the vinylidene complexes indicating the nucleophilic nature of the antecedent $\mathrm{C}_{\gamma}$ carbon of the vinylidene ligand. 
Thus, other electrophiles could also be added to this same $\mathrm{C}_{\gamma}$ site by reaction with cyclopropenyl complex.

\section{Experiment}

\subsection{Materials}

All manipulations were performed under nitrogen using vacuum-line, dry box, and standard Schlenk techniques. $\mathrm{CH}_{3} \mathrm{CN}$ and $\mathrm{CH}_{2} \mathrm{Cl}_{2}$ were distilled from $\mathrm{CaH}_{2}$ and diethyl ether and THF from $\mathrm{Na} /$ ketyl. All other solvents and reagents were of reagent grade and were used without further purification. NMR spectra were recorded on the Bruker AC-200 and AM-300WB FTNMR spectrometers at room temperature (unless stated otherwise) and are reported in units of $\delta$ with residual protons in the solvent as an internal standard $\left(\mathrm{CDCl}_{3}, \delta\right.$ 7.24; $\mathrm{CD}_{3} \mathrm{CN}, \delta$ 1.93; $\mathrm{C}_{2} \mathrm{D}_{6} \mathrm{CO}, \delta$ 2.04). FAB mass spectra were recorded on a JEOL SX-102A spectrometer. Complexes (1a) and $\mathrm{Cp}(\mathrm{dppe}) \mathrm{RuC} \equiv \mathrm{CPh}$ [39] were prepared following the method reported in the literature. Elemental analyses and X-ray diffraction studies were carried out at the Regional Center of Analytical Instrument located at the National Taiwan University.

\subsection{Preparation of Ru dppe complexes}

A Schlenk flask was charged with $\mathrm{Cp}\left(\mathrm{PPh}_{3}\right)_{2} \mathrm{RuCl}$, $1 \mathrm{a}(2.00 \mathrm{~g}, 2.76 \mathrm{mmol})$ and dppe $(1.21 \mathrm{~g}, 3.05 \mathrm{mmol})$ and the atmosphere was replaced with nitrogen, then $\mathrm{C}_{6} \mathrm{H}_{6}(60 \mathrm{ml})$ was added. The resulting solution was heated to reflux for $8 \mathrm{~h}$ to give a yellow solution with some precipitates. After filtration, $20 \mathrm{ml}$ of hexane was added to the filtrate to bring about more precipitation which was also filtered. The solid parts were combined to give two minor products trans- $\mathrm{RuCl}_{2}(\mathrm{dppe})_{2}(2)$ and $[\operatorname{RuClCp}(\mu \text {-dppe })]_{2}$ (3) which could be separated by recrystallization from 1:1 hexane: $\mathrm{CH}_{2} \mathrm{Cl}_{2}$. Complex 2 displays yellow and $\mathbf{3}$ displays red color. The solvent of the clear solution was reduced to about 10 and $80 \mathrm{ml}$ of hexane was added. The yellow precipitates thus formed were filtered and washed with diethyl ether and hexane to give the major product $\mathrm{Cp}(\mathrm{dppe}) \mathrm{RuCl}(1.15 \mathrm{~g}, 1.93$ mmol, $70 \%$ yield). Spectroscopic data of trans$\mathrm{RuCl}_{2}(\mathrm{dppe})_{2}$ (2): ${ }^{1} \mathrm{H} \mathrm{NMR}\left(\mathrm{CDCl}_{3}\right)$ : 7.23-6.90 (m, $40 \mathrm{H}, 8 \mathrm{Ph}), 2.80-2.65\left(\mathrm{~m}, 8 \mathrm{H}, \mathrm{CH}_{2}\right) .{ }^{31} \mathrm{P} \mathrm{NMR}\left(\mathrm{CDCl}_{3}\right)$ : 45.75. ${ }^{13} \mathrm{C}$ NMR $\left(\mathrm{CDCl}_{3}\right)$ : $135.6-126.8(\mathrm{~m}, \mathrm{Ph}), 30.2$ (d, $\left.\quad \mathrm{CH}_{2}, \quad J_{\mathrm{C}-\mathrm{P}}=12.1 \mathrm{~Hz}\right)$. Anal. Calcd. for $\mathrm{C}_{52} \mathrm{H}_{48} \mathrm{Cl}_{2} \mathrm{P}_{4} \mathrm{Ru}$ : C, 64.46; H, 4.99; Anal. Found: C, 64.30; H, 4.59. Spectroscopic data of $[\operatorname{RuClCp}(\mu-$ dppe) $]_{2}$ (3): ${ }^{1} \mathrm{H}$ NMR $\left(\mathrm{CDCl}_{3}\right): 7.50-6.90(\mathrm{~m}, \mathrm{Ph}), 3.85$ (s, Cp), 3.00-2.60 (m, 8H, $\left.\mathrm{CH}_{2}\right) .{ }^{31} \mathrm{P}$ NMR $\left(\mathrm{CDCl}_{3}\right)$ : 37.05. ${ }^{13} \mathrm{C}$ NMR $\left(\mathrm{CDCl}_{3}\right): 130.0-127.0(\mathrm{~m}, \mathrm{Ph}), 80.4$ (s, Cp), $24.2\left(\mathrm{~d}, \mathrm{CH}_{2} J_{\mathrm{C}-\mathrm{P}}=20.6 \mathrm{~Hz}\right) . \mathrm{MS}(\mathrm{m} / e$, FAB, $\left.20 \mathrm{ev}, \mathrm{Ru}^{102}\right)$ 968.1 (M+), $932.2\left(\mathrm{M}^{+}-\mathrm{Cl}\right), 897.2$
$\left(\mathrm{M}^{+}-2 \mathrm{Cl}\right)$. Anal. Calcd. for $\mathrm{C}_{62} \mathrm{H}_{58} \mathrm{Cl}_{2} \mathrm{P}_{4} \mathrm{Ru}_{2}$ : C, 62.05; H, 4.87; Anal. Found: C, 61.78; H, 4.96.

\subsection{Synthesis of [Cp(dppe) $\left.\mathrm{Ru}=\mathrm{C}=\mathrm{C}(\mathrm{Ph}) \mathrm{CH}_{2} \mathrm{CN}\right][\mathrm{I}]$, $5 \boldsymbol{a}$ and other vinylidene complexes}

To a $20 \mathrm{ml} \mathrm{CHCl}_{3}$ solution of complex $\mathrm{Cp}($ dppe $) \mathrm{RuC} \equiv \mathrm{CPh}(0.50 \mathrm{~g}, 0.75 \mathrm{mmol})$, an aliquot of $\mathrm{ICH}_{2} \mathrm{CN}(54.4 \mu \mathrm{l}, 0.75 \mathrm{mmol})$ was added. The solution was heated to reflux for $12 \mathrm{~h}$. Pink precipitates formed while the solution was allowed to cool to room temperature. The solvent was removed under vacuum and $20 \mathrm{ml}$ of ether was added then the mixture was filtered and the solid portion was washed with $20 \mathrm{ml}$ of hexane and 20 $\mathrm{ml}$ of diethyl ether and dried under vacuum to give the product $\left[\mathrm{Cp}(\right.$ dppe $\left.) \mathrm{Ru}=\mathrm{C}=\mathrm{C}(\mathrm{Ph}) \mathrm{CH}_{2} \mathrm{CN}\right][\mathrm{I}], \mathbf{5 a}(0.52 \mathrm{~g})$ in $83 \%$ yield. Spectroscopic data of 5a: ${ }^{1} \mathrm{H}$ NMR $\left(\mathrm{CDCl}_{3}\right): 7.60-6.60(\mathrm{~m}, 25 \mathrm{H}, \mathrm{Ph}), 5.60(\mathrm{~s}, 5 \mathrm{H}, \mathrm{Cp})$, $3.50-2.90\left(\mathrm{~m}, 4 \mathrm{H}, \mathrm{CH}_{2}\right), 2.52\left(\mathrm{~s}, 2 \mathrm{H}, \mathrm{CH}_{2} \mathrm{CN}\right) .{ }^{31} \mathrm{P}$ NMR $\left(\mathrm{CDCl}_{3}\right): 76.50 .{ }^{13} \mathrm{C}$ NMR $\left(\mathrm{CDCl}_{3}\right): 364.2(\mathrm{t}$, $\left.J_{\mathrm{C}-\mathrm{P}}=15.1 \mathrm{~Hz}, C_{\alpha}\right), 134.4-126.8\left(\mathrm{~m}, \mathrm{Ph}\right.$ and $\left.C_{\beta}\right)$, $122.1(C \mathrm{~N}), 92.5(\mathrm{Cp}), 28.1\left(\mathrm{~d}, C_{2}, J_{\mathrm{C}-\mathrm{P}}=10.0 \mathrm{~Hz}\right)$, $18.4\left(\mathrm{~s}, C \mathrm{H}_{2} \mathrm{CN}\right)$. MS $\left(\mathrm{m} / z, \mathrm{Ru}^{102}\right) 706.1\left(\mathrm{M}^{+}, 593.1\right.$ $\left(\mathrm{Cp}(\mathrm{dppe}) \mathrm{RuCO}^{+}\right), 565.1\left(\mathrm{Cp}(\mathrm{dppe}) \mathrm{Ru}^{+}\right)$. Anal. Calcd. for $\mathrm{C}_{41} \mathrm{H}_{36} \mathrm{NP}_{2}$ RuI: C, 59.14; H, 4.36; N, 1.68; Anal. Found: C, 60.07; H, 4.29, N, 1.50; Complexes 5b (yield $81 \%$ ), 5c (yield 79\%), 5d (yield 71\%), 5e (yield 74\%) and $\mathbf{5 f}$ (yield $80 \%$ ) were prepared using similar procedure. But for 5b-5f, the anion was replaced with $\mathrm{PF}_{6}^{-}$ by adding $\mathrm{NH}_{4} \mathrm{PF}_{6}$ to the cold solution after refluxing. $\mathrm{S} p$ e c t r o s c o p i c $\quad d$ a t a o f $\left[\mathrm{Cp}(\right.$ dppe $\left.) \mathrm{Ru}=\mathrm{C}=\mathrm{C}(\mathrm{Ph}) \mathrm{CH}_{2} \mathrm{C}_{6} \mathrm{~F}_{5}\right]\left[\mathrm{PF}_{6}\right](\mathbf{5 b}):{ }^{1} \mathrm{H} \mathrm{NMR}$ $\left(\mathrm{CDCl}_{3}\right): 7.80-6.50(\mathrm{~m}, \mathrm{Ph}), 5.58(\mathrm{~s}, 5 \mathrm{H}, \mathrm{Cp}), 3.60-$ $2.90\left(\mathrm{~m}, 4 \mathrm{H}, \mathrm{CH}_{2}\right), 2.80\left(\mathrm{~s}, 2 \mathrm{H}, \mathrm{CH}_{2} \mathrm{C}_{6} \mathrm{~F}_{5}\right) .{ }^{31} \mathrm{P} \mathrm{NMR}$ $\left(\mathrm{CDCl}_{3}\right): 76.97 .{ }^{3} \mathrm{C} \mathrm{NMR}\left(\mathrm{CDCl}_{3}\right): 343.0\left(\mathrm{t}, J_{\mathrm{C}-\mathrm{P}}=\right.$ $\left.12.1 \mathrm{~Hz}, C_{\alpha}\right), 135.8-126.2(\mathrm{~m}, \mathrm{Ph}), 112.3\left(C_{\beta}\right), 91.9$ (Cp), $27.4\left(\mathrm{~d}, \mathrm{CH}_{2}, \mathrm{~J}_{\mathrm{C}-\mathrm{P}}=24.3 \mathrm{~Hz}\right), 17.1\left(\mathrm{CH}_{2} \mathrm{C}_{6} \mathrm{~F}_{5}\right)$. MS $(m / z): 847.1\left(\mathrm{M}^{+}\right), 593.1\left(\mathrm{Cp}(\mathrm{dppe}) \mathrm{RuCO}^{+}\right)$, $565.1\left(\mathrm{Cp}(\mathrm{dppe}) \mathrm{Ru}^{+}\right)$. Anal. Calcd. for $\mathrm{C}_{46} \mathrm{H}_{36} \mathrm{~F}_{11} \mathrm{P}_{3} \mathrm{Ru}$ : C, 55.71; H, 3.66; Anal. Found: C, 55.90; H, 3.86 . Spectroscopic data of $\left[\mathrm{Cp}(\right.$ dppe $) \mathrm{Ru}=\mathrm{C}=\mathrm{C}(\mathrm{Ph})_{-}$ $\left.\mathrm{CH}_{2} \mathrm{C}_{6} \mathrm{H}_{5}\right]\left[\mathrm{PF}_{6}\right](\mathbf{5 c}):{ }^{1} \mathrm{H}$ NMR $\left(\mathrm{CDCl}_{3}\right): 7.50-6.60$ $(\mathrm{m}, \mathrm{Ph}), 5.52(\mathrm{~s}, 5 \mathrm{H}, \mathrm{Cp}), 3.50-2.90\left(\mathrm{~m}, 4 \mathrm{H}, \mathrm{CH}_{2}\right)$, $2.85\left(\mathrm{~s}, 2 \mathrm{H}, \mathrm{CH}_{2} \mathrm{C}_{6} \mathrm{H}_{5}\right),{ }^{31} \mathrm{P}$ NMR $\left(\mathrm{CDCl}_{3}\right): 77.65 .{ }^{13} \mathrm{C}$ NMR $\left(\mathrm{CDCl}_{3}\right): 349.0\left(\mathrm{t}, J_{\mathrm{C}-\mathrm{P}}=16.4 \mathrm{~Hz}, C_{\alpha}\right), 138.0-$ $126.5(\mathrm{~m}, \mathrm{Ph}), 125.1\left(C_{\beta}\right), 91.7(\mathrm{Cp}), 28.7\left(\mathrm{~d}, \mathrm{CH}_{2}\right.$, $\left.J_{\mathrm{C}-\mathrm{P}}=25.0 \mathrm{~Hz}\right), 29.6\left(\mathrm{CH}_{2} \mathrm{C}_{6} \mathrm{H}_{5}\right)$. MS $(\mathrm{m} / \mathrm{z}): 757.1$ $\left(\mathrm{M}^{+}-\mathrm{PF}_{6}\right), \quad 593.1 \quad\left(\mathrm{Cp}(\mathrm{dppe}) \mathrm{RuCO}^{+}\right), \quad 565.1$ $\left(\mathrm{Cp}(\right.$ dppe $\left.) \mathrm{Ru}^{+}\right)$. Anal. Calcd. for $\mathrm{C}_{46} \mathrm{H}_{41} \mathrm{~F}_{6} \mathrm{P}_{3} \mathrm{Ru}$ : C, 61.26; H, 4.58; Anal. Found: C, 60.97; H, 4.67. Spectroscopic data of $\left[\mathrm{Cp}(\right.$ dppe $) \mathrm{Ru}=\mathrm{C}=\mathrm{C}(\mathrm{Ph}) \mathrm{CH}_{2}(p-$ $\left.\left.\mathrm{C}_{6} \mathrm{H}_{4} \mathrm{CN}\right)\right]\left[\mathrm{PF}_{6}\right](\mathbf{5 d}):{ }^{1} \mathrm{H}$ NMR $\left(\mathrm{CDCl}_{3}\right): 7.80-6.40(\mathrm{~m}$, $\mathrm{Ph}$ ), 5.59 (s, 5H, Cp), 3.50-3.10 (m, 4H, $\left.\mathrm{CH}_{2}\right), 2.93$ (s, $2 \mathrm{H}, \mathrm{CH}_{2}\left(p-\mathrm{C}_{6} \mathrm{H}_{4} \mathrm{CN}\right) .{ }^{31} \mathrm{P} \mathrm{NMR}\left(\mathrm{CDCl}_{3}\right): 77.40 .{ }^{13} \mathrm{C}$ NMR $\left(\mathrm{CDCl}_{3}\right): 347.2\left(\mathrm{t}, J_{\mathrm{C}-\mathrm{P}}=18.1 \mathrm{~Hz}, C_{\alpha}\right), 132.5-$ $126.8(\mathrm{~m}, \mathrm{Ph}), 118.7\left(C_{\alpha}\right), 109.9\left(C_{\beta}\right), 88.1(\mathrm{Cp}), 28.2$ 
(d, $\left.\mathrm{CH}_{2}, J_{\mathrm{C}-\mathrm{P}}=46.8 \mathrm{~Hz}\right), 29.4\left(\mathrm{CH}_{2} p-\mathrm{C}_{6} \mathrm{H}_{4} \mathrm{CN}\right)$. $\operatorname{MS}(m / z): 782.1\left(\mathrm{M}^{+}-\mathrm{PF}_{6}\right), 593.1\left(\mathrm{Cp}(\right.$ dppe $\left.) \mathrm{RuCO}^{+}\right)$, 565.1 (Cp(dppe)Ru $\left.{ }^{+}\right)$. Anal. Calcd. for $\mathrm{C}_{47} \mathrm{H}_{40} \mathrm{~F}_{6} \mathrm{NP}_{3} \mathrm{Ru}: \mathrm{C}, 60.91 ; \mathrm{H}, 4.35 ; \mathrm{N}, 1.51$; Anal. Found: $\mathrm{C}, 60.65 ; \mathrm{H}, 4.30 ; \mathrm{N}, 1.43$. Spectroscopic data of $\left[\mathrm{Cp}(\mathrm{dppe}) \mathrm{Ru}=\mathrm{C}=\mathrm{C}(\mathrm{Ph}) \mathrm{CH}_{2}\left(p-\mathrm{C}_{6} \mathrm{H}_{4} \mathrm{CF}_{3}\right)\right]\left[\mathrm{PF}_{6}\right]$ (5e): ${ }^{1} \mathrm{H}$ NMR $\left(\mathrm{CDCl}_{3}\right): 7.50-6.40(\mathrm{~m}, \mathrm{Ph}), 5.54(\mathrm{~s}$, $5 \mathrm{H}, \mathrm{Cp}), 3.20-2.80\left(\mathrm{~m}, 4 \mathrm{H}, \mathrm{CH}_{2}\right), 2.91\left(\mathrm{~s}, 2 \mathrm{H}, \mathrm{CH}_{2}(p-\right.$ $\left.\mathrm{C}_{6} \mathrm{H}_{4} \mathrm{CF}_{3}\right) .{ }^{31} \mathrm{P}$ NMR $\left(\mathrm{CDCl}_{3}\right): 77.33 .{ }^{13} \mathrm{C} \quad \mathrm{NMR}$ $\left(\mathrm{CDCl}_{3}\right): 343.1\left(\mathrm{t}, J_{\mathrm{C}-\mathrm{P}}=12.1 \mathrm{~Hz}, C_{\alpha}\right), 135.8-126.2$ $(\mathrm{m}, \mathrm{Ph}), 112.3\left(C_{\beta}\right), 91.9(\mathrm{Cp}), 27.7\left(\mathrm{~d}, C \mathrm{H}_{2}, J_{\mathrm{C}-\mathrm{P}}=\right.$ $14.1 \mathrm{~Hz}), 17.1\left(\mathrm{CH}_{2}\left(p-\mathrm{C}_{6} \mathrm{H}_{4} \mathrm{CF}_{3}\right) . \mathrm{MS}(\mathrm{m} / z): 825.1\right.$ $\left(\mathrm{M}^{+}-\mathrm{PF}_{6}\right), \quad 593.1 \quad\left(\mathrm{Cp}(\mathrm{dppe}) \mathrm{RuCO}^{+}\right), \quad 565.1$ $\left(\mathrm{Cp}(\right.$ dppe $\left.) \mathrm{Ru}^{+}\right)$. Anal. Calcd. for $\mathrm{C}_{47} \mathrm{H}_{40} \mathrm{~F}_{9} \mathrm{P}_{3} \mathrm{Ru}$ : C, 58.21; H, 4.16; Anal. Found: C, 58.30; H, 4.39. Spectroscopic data of $\left[\mathrm{Cp}(\right.$ dppe $) \mathrm{Ru}=\mathrm{C}=\mathrm{C}(\mathrm{Ph}) \mathrm{CH}_{2}(1-$ $\left.\left.\mathrm{C}_{10} \mathrm{H}_{7}\right)\right]\left[\mathrm{PF}_{6}\right](\mathbf{5 f}):{ }^{1} \mathrm{H}$ NMR $\left(\mathrm{CDCl}_{3}\right): 7.80-6.50(\mathrm{~m}$, $\mathrm{Ph}), 5.53$ (s, 5H, Cp), 3.20-2.90 (m, 4H, $\left.\mathrm{CH}_{2}\right), 2.98$ (s, $\left.2 \mathrm{H}, \mathrm{CH}_{2}\left(1-\mathrm{C}_{10} \mathrm{H}_{7}\right)\right) .{ }^{31} \mathrm{P} \mathrm{NMR}\left(\mathrm{CDCl}_{3}\right): 77.40 .{ }^{13} \mathrm{C}$ NMR $\left(\mathrm{CDCl}_{3}\right): 343.6\left(\mathrm{t}, J_{\mathrm{C}-\mathrm{P}}=10.2 \mathrm{~Hz}, C_{\alpha}\right), 136.1-$ $125.4\left(\mathrm{~m}, \mathrm{Ph}\right.$ and $\left.\mathrm{C}_{\beta}\right), 91.7(\mathrm{Cp}), 30.8\left(\mathrm{CH}_{2}\left(1-\mathrm{C}_{10} \mathrm{H}_{7}\right)\right)$, $28.2\left(\mathrm{~d}, \mathrm{CH}_{2}, J_{\mathrm{C}-\mathrm{P}}=14.1 \mathrm{~Hz}\right) . \mathrm{MS}(\mathrm{m} / \mathrm{z}): 807.1$ $\left(\mathrm{M}^{+}-\mathrm{PF}_{6}\right), \quad 593.1 \quad\left(\mathrm{Cp}(\mathrm{dppe}) \mathrm{RuCO}^{+}\right), \quad 565.1$ $\left(\mathrm{Cp}(\right.$ dppe $\left.) \mathrm{Ru}^{+}\right)$. Anal. Calcd. for $\mathrm{C}_{50} \mathrm{H}_{43} \mathrm{~F}_{6} \mathrm{P}_{3} \mathrm{Ru}$ : C, 63.09; H, 4.55; Anal. Found: C, 63.24; H, 4.72.

\subsection{Preparation of $\mathbf{5 g}$}

To a $20 \mathrm{ml} \mathrm{CHCl}_{3}$ solution of complex $\mathrm{Cp}($ dppe $) \mathrm{RuC} \equiv \mathrm{CPh}(0.30 \mathrm{~g}, 0.45 \mathrm{mmol})$, an aliquot of $\mathrm{BrCH}_{2} \mathrm{CO}_{2} \mathrm{CH}_{3}(142 \mu \mathrm{l}, 1.5 \mathrm{mmol})$ was added. The solution was heated to reflux for $24 \mathrm{~h}$. Then the solvent was removed under vacuum and $20 \mathrm{ml}$ of ether was added and the slurry was filtered. These solids were washed with $20 \mathrm{ml}$ of hexane and $20 \mathrm{ml}$ of ether and dried under vacuum to give the product $\mathrm{Cp}($ dppe $) \mathrm{Ru}=\mathrm{C}=\mathrm{C}(\mathrm{Ph}) \mathrm{CH}_{2} \mathrm{CO}_{2} \mathrm{CH}_{3}^{+} \mathrm{Br}^{-},(\mathbf{5 g})(0.35 \mathrm{~g})$ in $94 \%$ yield. Spectroscopic data of $5 \mathrm{~g}:{ }^{1} \mathrm{H}$ NMR $\left(\mathrm{CDCl}_{3}\right): 8.00-6.50(\mathrm{~m}, \mathrm{Ph}), 5.65(\mathrm{~s}, 5 \mathrm{H}, \mathrm{Cp}), 3.50$ $3.00\left(\mathrm{~m}, 4 \mathrm{H}, \mathrm{CH}_{2}\right), 3.49\left(\mathrm{~s}, 3 \mathrm{H}, \mathrm{CH}_{3}\right), 2.35(\mathrm{~s}, 2 \mathrm{H}$, $\left.\mathrm{CH}_{2}\right) .{ }^{31} \mathrm{P} \mathrm{NMR}\left(\mathrm{CDCl}_{3}\right): 76.86 .{ }^{13} \mathrm{C} \mathrm{NMR}\left(\mathrm{CDCl}_{3}\right)$ : $349.8\left(\mathrm{t}, J_{\mathrm{C}-\mathrm{P}}=16.1 \mathrm{~Hz}, C_{\alpha}\right), 172.5\left(\mathrm{CO}_{2}\right), 135.6-$ $125.3(\mathrm{Ph}), 123.6\left(C_{\beta}\right), 92.9(\mathrm{Cp}), 51.7\left(\mathrm{CH}_{2} \mathrm{CO}_{2}\right)$, $29.3\left(\mathrm{OCH}_{3}\right), 27.6\left(\mathrm{~d}, \mathrm{CH}_{2} \mathrm{CH}_{2}, J_{\mathrm{C}-\mathrm{P}}=30.1 \mathrm{~Hz}\right) . \mathrm{MS}$ $(\mathrm{m} / \mathrm{z}): 739.1\left(\mathrm{M}^{+}-\mathrm{PF}_{6}\right), 593.1 \quad\left(\mathrm{Cp}(\mathrm{dppe}) \mathrm{RuCO}^{+}\right)$, 565.1 (Cp(dppe)Ru $\left.{ }^{+}\right)$. Anal. Calcd. for $\mathrm{C}_{42} \mathrm{H}_{39} \mathrm{BrO}_{2} \mathrm{P}_{2} \mathrm{Ru}$ : C, 61.62; H, 4.80; Anal. Found: C, $61.44 ; \mathbf{H}, 4.56$. Complex $\mathbf{5} \mathbf{g}^{\prime}$ is also prepared by carrying out the reaction at room temperature. The yield $(76 \%)$ is lower.

\subsection{Formation of $\mathrm{Cp}($ dppe $) \mathrm{RUCOCH} \mathrm{CH}_{2} \mathrm{Ph}$ (6rom $\mathbf{5} \boldsymbol{g}^{\prime}$}

Complex 5 $\mathbf{g}^{\prime}$ (0.30 g, $\left.0.36 \mathrm{mmol}\right)$, prepared at room temperature, was dissolved in $20 \mathrm{ml}$ of $\mathrm{CHCl}_{3}$ and $\mathrm{NH}_{4} \mathrm{PF}_{6}(0.30 \mathrm{~g})$ was added. And the solution was stirred at room temperature for $24 \mathrm{~h}$. Then the solvent was removed under vacuum and the residue was washed with $2 \times 20 \mathrm{ml}$ of hexane and $2 \times 20 \mathrm{ml}$ of ether to give the product $6(0.16 \mathrm{~g}, 64 \%$ yield $)$. Spectroscopic data of (6): ${ }^{1} \mathrm{H}$ NMR $\left(\mathrm{CDCl}_{3}\right): 7.80-6.00(\mathrm{~m}, \mathrm{Ph}), 4.84(\mathrm{~s}, 5 \mathrm{H}$, $\mathrm{Cp}), 3.38\left(\mathrm{~s}, 2 \mathrm{H}, \mathrm{CH}_{2}\right), 3.00-2.50\left(\mathrm{~m}, 4 \mathrm{H}, \mathrm{CH}_{2}\right) .{ }^{31} \mathrm{P}$ $\operatorname{NMR}\left(\mathrm{CDCl}_{3}\right): 91.10 .{ }^{13} \mathrm{C} \mathrm{NMR}\left(\mathrm{CDCl}_{3}\right): 254.4(\mathrm{t}$, $\left.J_{\mathrm{C}-\mathrm{P}}=13.4 \mathrm{~Hz}, C \mathrm{O}\right), 139.7-127.8\left(\mathrm{~m}, \mathrm{Ph}\right.$ and $\left.\mathrm{C}_{\beta}\right)$, $87.5(\mathrm{Cp}), 60.9\left(\mathrm{COCH}_{2}\right), 27.5\left(\mathrm{t}, \mathrm{CH}_{2} \mathrm{CH}_{2}, J_{\mathrm{C}-\mathrm{P}}=\right.$ $22.5 \mathrm{~Hz})$. MS $(m / z)$ : $684.1 \quad\left(\mathrm{M}^{+}\right)$, 593.1(Cp(dppe)RuCO $\left.{ }^{+}\right)$, $565.1\left(\mathrm{Cp}(\mathrm{dppe}) \mathrm{Ru}^{+}\right)$. Anal. Calcd. for $\mathrm{C}_{39} \mathrm{H}_{36} \mathrm{OP}_{2} \mathrm{Ru}$ : C, 68.51; H, 5.31; Anal. Found: C, 68.38; H, 5.49.

\subsection{Preparation of cyclopropenyl complexes}

To a $15 \mathrm{ml}$ acetone solution of complex 5a $(0.50 \mathrm{~g}$, $0.60 \mathrm{mmol})$ an aliquot of $(n-\mathrm{Bu})_{4} \mathrm{NOH}(10 \mathrm{ml})$ was added. The mixture was stirred at room temperature for $1 \mathrm{~h}$ to give a bright yellow solution and then the solvent was removed under vacuum. To the residue, $15 \mathrm{ml}$ of $\mathrm{CH}_{3} \mathrm{CN}$ was added and the yellow precipitates was filtered.

The solid residue was further washed with $2 \times 20 \mathrm{ml}$ of hexane and $2 \times 20 \mathrm{ml}$ of $\mathrm{CH}_{3} \mathrm{CN}$ and dried under vacuum to give the product identified as $\mathrm{Cp}$ (dppe) $\mathrm{Ru}-\mathrm{C}=(\mathrm{Ph}) \mathrm{C} H C N, 7 \mathbf{a}(0.30 \mathrm{~g}, 0.42 \mathrm{mmol})$ in $72 \%$ yield. Spectroscopic data of $7 \mathbf{a}:{ }^{1} \mathrm{H}$ NMR $\left(\mathrm{CD}_{3} \mathrm{COCD}_{3}\right): 7.80-6.30(\mathrm{~m}, \mathrm{Ph}), 4.95(\mathrm{~s}, 5 \mathrm{H}, \mathrm{Cp})$, $3.80-3.50\left(\mathrm{~m}, 4 \mathrm{H}, \mathrm{PCH}_{2}\right), 2.13(\mathrm{~s}, \mathrm{H}, \mathrm{CHCN}) .{ }^{31} \mathrm{P}$ NMR $\left(\mathrm{CDCl}_{3}\right): 90.14,88.47$ (two doublet with $J_{\mathrm{P}-\mathrm{P}}=$ $24.3 \mathrm{~Hz}) .{ }^{13} \mathrm{C}$ NMR $\left(\mathrm{CDCl}_{3}\right)$ : 134.5-126.0 (m, Ph), $124.6(C \mathrm{~N}), 84.1(\mathrm{Cp}), 32.9,29.1\left(\mathrm{~d}, 2 \mathrm{PCH}_{2}\right), 6.2$ $(C \mathrm{HCN})$. MS $(m / z): 706.1 \quad\left(\mathrm{M}^{+}+1\right)$, 593.1(Cp(dppe)RuCO $\left.{ }^{+}\right), 565.1\left(\mathrm{Cp}(\mathrm{dppe}) \mathrm{Ru}^{+}\right)$. Anal. Calcd. for $\mathrm{C}_{41} \mathrm{H}_{35} \mathrm{NP}_{2} \mathrm{Ru}$ : C, 69.87; H, 5.01; N, 1.99; Anal. Found: C, 69.64; H, 4.87; N, 1.79. Complexes 7b, 7c, 7d, 7e and 7f were similarly prepared. Spectroscopic data of $\mathrm{Cp}($ dppe $) \mathrm{Ru}-\mathrm{C}=(\mathrm{Ph}) \mathrm{CHC}_{6} \mathrm{~F}_{5} \quad(\mathbf{7 b}):{ }^{1} \mathrm{H} \quad \mathrm{NMR}$ $\left(\mathrm{CDCl}_{3}\right): 8.00-6.30(\mathrm{~m}, \mathrm{Ph}), 4.70(\mathrm{~s}, 5 \mathrm{H}, \mathrm{Cp}), 3.00-$ $2.30\left(\mathrm{~m}, 4 \mathrm{H}, \mathrm{PCH}_{2}\right), 2.90\left(\mathrm{~s}, 1 \mathrm{H}, \mathrm{CHC}_{6} \mathrm{~F}_{5}\right) .{ }^{31} \mathrm{P} \mathrm{NMR}$ $\left(\mathrm{CDCl}_{3}\right): 91.15,88.45$ (two doublet with $J_{\mathrm{P}-\mathrm{P}} 26.7 \mathrm{~Hz}$ ). ${ }^{13} \mathrm{C}$ NMR $\left(\mathrm{CDCl}_{3}\right):$ 144.4-117.3 (m, Ph), $83.2(\mathrm{Cp})$, $28.8\left(\mathrm{dd}, \quad \mathrm{CH}_{2},{ }^{1} J_{\mathrm{C}-\mathrm{P}}=32.3 \mathrm{~Hz},{ }^{2} J_{\mathrm{C}-\mathrm{P}}=15.1\right.$ $\mathrm{Hz}), 26.7\left(\mathrm{dd}, \mathrm{CH}_{2},{ }^{1} J_{\mathrm{C}-\mathrm{P}}=34.7 \mathrm{~Hz},{ }^{2} J_{\mathrm{C}-\mathrm{P}}=15.8 \mathrm{~Hz}\right)$, 19.1 $\left(\mathrm{CHC}_{6} \mathrm{~F}_{5}\right)$. MS $(\mathrm{m} / \mathrm{z}): 847.2\left(\mathrm{M}^{+}+1\right), 593.2$ $\left(\mathrm{Cp}(\mathrm{dppe}) \mathrm{RuCO}^{+}\right), 565.2\left(\mathrm{Cp}(\mathrm{dppe}) \mathrm{Ru}^{+}\right)$. Anal. Calcd. for $\mathrm{C}_{46} \mathrm{H}_{35} \mathrm{~F}_{5} \mathrm{P}_{2} \mathrm{Ru}$ : C, 65.32; H, 4.17; Anal. Found: C, 65.47; H, 4.34. Spectroscopic data of $\mathrm{Cp}($ dppe $) \mathrm{Ru}-\mathrm{C}=(\mathrm{Ph}) \mathrm{CHC}_{6} \mathrm{H}_{5}(\mathbf{7 c}):{ }^{1} \mathrm{H}$ NMR $\left(\mathrm{CDCl}_{3}\right)$ : 7.50-6.60 (m, Ph), 4.66 (s, 5H, Cp), 3.40-2.90 (m, 4H, $\left.\mathrm{CH}_{2}\right), 2.75\left(\mathrm{~s}, 1 \mathrm{H}, \mathrm{CHC}_{6} \mathrm{H}_{5}\right) .{ }^{31} \mathrm{P}$ NMR $\left(\mathrm{CDCl}_{3}\right)$ : 91.58, 90.18(two doublet with $J_{\mathrm{P}-\mathrm{P}} 25.5 \mathrm{~Hz}$ ). ${ }^{13} \mathrm{C}$ NMR $\left(\mathrm{CDCl}_{3}\right): 135.9-122.3(\mathrm{~m}, \mathrm{Ph}), 83.2(\mathrm{Cp}), 27.3,26.7$ $\left(\mathrm{CH}_{2} \mathrm{CH}_{2}\right), 30.4\left(\mathrm{CHC}_{6} \mathrm{H}_{5}\right)$. MS $(\mathrm{m} / \mathrm{z}): 756.1\left(\mathrm{M}^{+}\right.$ 
+ 1), $593.1\left(\mathrm{Cp}(\mathrm{dppe}) \mathrm{RuCO}^{+}\right), 565.1\left(\mathrm{Cp}(\mathrm{dppe}) \mathrm{Ru}^{+}\right)$. Anal. Calcd. for $\mathrm{C}_{46} \mathrm{H}_{40} \mathrm{P}_{2} \mathrm{Ru}$ : C, 73.10; H, 5.33; Anal. Found: $\mathrm{C}, 73.22 ; \mathrm{H}$, 5.47. Spectroscopic data of $\mathrm{Cp}($ dppe $) \mathrm{Ru}-\mathrm{C}=(\mathrm{Ph}) \mathrm{C} H\left(p-\mathrm{C}_{6} \mathrm{H}_{4} \mathrm{CN}\right) \quad$ (7d): ${ }^{1} \mathrm{H} \quad \mathrm{NMR}$ $\left(\mathrm{CDCl}_{3}\right): 7.80-6.20(\mathrm{~m}, \mathrm{Ph}), 4.56(\mathrm{~s}, 5 \mathrm{H}, \mathrm{Cp}), 3.40-$ $3.20\left(\mathrm{~m}, 4 \mathrm{H}, \mathrm{CH}_{2}\right), 2.60\left(\mathrm{~s}, 1 \mathrm{H}, \mathrm{CH}\left(p-\mathrm{C}_{6} \mathrm{H}_{4} \mathrm{CN}\right)\right) .{ }^{31} \mathrm{P}$ $\operatorname{NMR}\left(\mathrm{CDCl}_{3}\right): 90.54,89.54$ (two doublet with $J_{\mathrm{P}-\mathrm{P}}=$ $24.3 \mathrm{~Hz}) .{ }^{13} \mathrm{C}$ NMR $\left(\mathrm{CDCl}_{3}\right): 134.3-125.6(\mathrm{~m}, \mathrm{Ph}$ and $\left.\mathrm{C}_{\alpha}\right), 120.62(\mathrm{CN}), 83.0(\mathrm{Cp}), 27.4,27.3\left(\mathrm{CH}_{2} \mathrm{CH}_{2}\right)$, $32.3\left(\mathrm{CH}\left(p-\mathrm{C}_{6} \mathrm{H}_{4} \mathrm{CN}\right)\right)$. MS $(m / z): 847.2\left(\mathrm{M}^{+}+1\right)$, $593.2\left(\mathrm{Cp}(\mathrm{dppe}) \mathrm{RuCO}^{+}\right), 565.2\left(\mathrm{Cp}(\mathrm{dppe}) \mathrm{Ru}^{+}\right)$. Anal. Calcd. for $\mathrm{C}_{47} \mathrm{H}_{39} \mathrm{NP}_{2} \mathrm{Ru}$ : C, 72.29; H, 5.03; Anal. Found: C, 72.31; H, 4.89. Spectroscopic data of $\mathrm{Cp}($ dppe $) \mathrm{Ru}-\mathrm{C}=(\mathrm{Ph}) \mathrm{C} H\left(p-\mathrm{C}_{6} \mathrm{H}_{4} \mathrm{CF}_{3}\right) \quad(7 \mathrm{e}):{ }^{1} \mathrm{H} \quad \mathrm{NMR}$ $\left(\mathrm{CDCl}_{3}\right): 8.02-6.22(\mathrm{~m}, \mathrm{Ph}), 4.64(\mathrm{~s}, 5 \mathrm{H}, \mathrm{Cp}), 3.00-$ $2.30\left(\mathrm{~m}, 4 \mathrm{H}, \mathrm{CH}_{2}\right), 2.19\left(\mathrm{~s}, 1 \mathrm{H}, \mathrm{CH}\left(p-\mathrm{C}_{6} \mathrm{H}_{4} \mathrm{CF}_{3}\right)\right) .{ }^{31} \mathrm{P}$ NMR $\left(\mathrm{CDCl}_{3}\right): 91.03,89.82$ (two doublet with $\left.J_{\mathrm{P}-\mathrm{P}} 25.5 \mathrm{~Hz}\right) .{ }^{13} \mathrm{C} \mathrm{NMR}\left(\mathrm{CDCl}_{3}\right): 144.3-123.7(\mathrm{~m}$, $\mathrm{Ph}), 83.2(\mathrm{Cp}), 28.7\left(\mathrm{dd}, \mathrm{CH}_{2} \mathrm{CH}_{2},{ }^{1} J_{\mathrm{C}-\mathrm{P}}=33.9 \mathrm{~Hz}\right.$, $\left.{ }^{2} J_{\mathrm{C}-\mathrm{P}}=16.0 \mathrm{~Hz}\right), 26.8\left(\mathrm{dd}, \mathrm{CH}_{2} \mathrm{CH}_{2},{ }^{1} J_{\mathrm{C}-\mathrm{P}}=29.0\right.$ $\left.\mathrm{Hz},{ }^{2} J_{\mathrm{C}-\mathrm{P}}=15.7 \mathrm{~Hz}\right), 13.6\left(\mathrm{CH}\left(p-\mathrm{C}_{6} \mathrm{H}_{4} \mathrm{CF}_{3}\right)\right)$. MS $(\mathrm{m} / \mathrm{z}): 825.2\left(\mathrm{M}^{+}+1\right), \quad 593.2\left(\mathrm{Cp}(\mathrm{dppe}) \mathrm{RuCO}^{+}\right)$, 565.2 (Cp(dppe) $\left.\mathrm{Ru}^{+}\right)$. Anal. Calcd. for $\mathrm{C}_{47} \mathrm{H}_{39} \mathrm{~F}_{3} \mathrm{P}_{2} \mathrm{Ru}$ : C, 68.52; H, 4.77; Anal. Found: C, 68.35; H, 4.67. Spectroscopic data of $\mathrm{Cp}($ dppe $) \mathrm{Ru}-\mathrm{C}=(\mathrm{Ph}) \mathrm{CH}\left(1-\mathrm{C}_{10} \mathrm{H}_{7}\right)$ (7f): ${ }^{1} \mathrm{H} \mathrm{NMR}\left(\mathrm{CDCl}_{3}\right): 8.10-6.40(\mathrm{~m}, \mathrm{Ph}), 4.63(\mathrm{~s}, 5 \mathrm{H}$, Cp), 3.00-2.30 (m, 4H, $\left.\mathrm{CH}_{2}\right), 1.98(\mathrm{~s}, 1 \mathrm{H}, \mathrm{CH}(1-$ $\left.\mathrm{C}_{10} \mathrm{H}_{7}\right)$ ). ${ }^{31} \mathrm{P}$ NMR $\left(\mathrm{CDCl}_{3}\right): 91.39,90.17$ (two doublet with $\left.J_{\mathrm{P}-\mathrm{P}}=25.5 \mathrm{~Hz}\right) .{ }^{13} \mathrm{C} \mathrm{NMR}\left(\mathrm{CDCl}_{3}\right): 135.2-122.3$ $(\mathrm{m}, \mathrm{Ph}), 83.2(\mathrm{Cp}), 24.1\left(\mathrm{CH}\left(1-{ }_{10} \mathrm{H}_{7}\right)\right), 28.1,27.0$ $\left(\mathrm{CH}_{2} \mathrm{CH}_{2}\right)$. MS $(\mathrm{m} / \mathrm{z}): \quad 807.1\left(\mathrm{M}^{+}+1\right), \quad 593.1$ $\left(\mathrm{Cp}(\mathrm{dppe}) \mathrm{RuCO}^{+}\right), 565.1\left(\mathrm{Cp}(\mathrm{dppe}) \mathrm{Ru}^{+}\right)$. Anal. Calcd. for $\mathrm{C}_{50} \mathrm{H}_{42} \mathrm{P}_{2} \mathrm{Ru}: \mathrm{C}, 74.52 ; \mathrm{H}, 5.25$; Anal. Found: C, 74.22; H, 5.03 .

\subsection{Synthesis of $\left[[\mathrm{Ru}]=\mathrm{C}=\mathrm{C}(\mathrm{Ph}) \mathrm{CH}\left(\mathrm{C}_{6} \mathrm{~F}_{5}\right) \mathrm{HgCl} \mathrm{Cl}\right.$} (8b)

To a mixture of $7 \mathbf{b}(0.20 \mathrm{~g}, 0.24 \mathrm{mmol})$, and $\mathrm{HgCl}_{2}$ $(0.076 \mathrm{~g}, 0.28 \mathrm{mmol})$ at room temperature, $15 \mathrm{ml}$ of $\mathrm{CH}_{2} \mathrm{Cl}_{2}$ was added by syringe. The mixture was stirred under nitrogen for $5 \mathrm{~min}$. The work-up procedure was the same as that in $\mathbf{5 b}$. The product $\mathbf{8 b}$ was obtained $(0.21 \mathrm{~g}, 86 \%)$ and $\mathrm{w}$ as identified as $\mathrm{Cp}($ dppe $) \mathrm{Ru}=\mathrm{C}=\mathrm{C}(\mathrm{Ph}) \mathrm{CH}\left(\mathrm{C}_{6} \mathrm{~F}_{5}\right)(\mathrm{HgCl})^{+} \mathrm{Cl}^{-}$. Spectroscopic data of 8b: ${ }^{1} \mathrm{H}$ NMR $\left(\mathrm{CDCl}_{3}\right)$ : 7.67-6.60 (m, $\mathrm{Ph}), 5.59$ (s, 5H, Cp), 3.40-2.90 (m, 4H, $\left.\mathrm{CH}_{2}\right), 3.38$ (s, $1 \mathrm{H}, \mathrm{CHHgCl}$ ). ${ }^{31} \mathrm{P}$ NMR $\left(\mathrm{CDCl}_{3}\right): 78.59,78.10$ (two doublet with $\left.J_{\mathrm{P}-\mathrm{P}}=18.2 \mathrm{~Hz}\right) .{ }^{13} \mathrm{C} \mathrm{NMR}\left(\mathrm{CDCl}_{3}\right)$ : 133.0-127.0 (m, Ph and $\left.\mathrm{C}_{\beta}\right), 92.1(\mathrm{Cp}), 47.7(\mathrm{~s}, \mathrm{H}$, $\mathrm{CHHgCl}), 28.8,27.7\left(\mathrm{~d}, \mathrm{CH}_{2} \mathrm{CH}_{2}, J_{\mathrm{C}-\mathrm{P}}=15.9 \mathrm{~Hz}\right)$. MS $(m / z): 1083.1\left(\mathrm{M}^{+}-\mathrm{Cl}\right), 593.2\left(\mathrm{Cp}(\mathrm{dppe}) \mathrm{RuCO}^{+}\right)$, $565.2\left(\mathrm{Cp}(\mathrm{dppe}) \mathrm{Ru}^{+}\right)$.

\subsection{Dimerization of $7 \boldsymbol{a}$ in the presence of allyl iodide}

Excess freshly distilled allyl iodide $(0.65 \mathrm{ml}, 7.1$ mmol) was added to a solution of $7 \mathbf{a}(0.20 \mathrm{~g}, 0.28$ mmol) in $10 \mathrm{ml} \mathrm{CHCl}_{3}$. This mixture was stirred at room temperature for $48 \mathrm{~h}$ to give orange red precipitate which was filtered off, washed with $10 \mathrm{ml}$ of acetone and $2 \times 10 \mathrm{ml}$ of hexane, then dried in vacuo yielding $[[\mathrm{Ru}]=\mathrm{C}=\mathrm{C}(\mathrm{Ph}) \mathrm{CH}(\mathrm{CN})]_{2} \mathrm{I}_{2}$ (9a) $(0.13 \mathrm{~g}, 39 \%$ yield $)$. Complex 9a is insoluble in common organic solvents except DMSO. Spectroscopic data of (9a): ${ }^{1} \mathrm{H}$ $\operatorname{NMR}\left(\mathrm{CDCl}_{3}\right): 7.40-6.80(\mathrm{~m}, \mathrm{Ph}), 5.30(\mathrm{~s}, 10 \mathrm{H}, \mathrm{Cp})$, $3.20-2.60\left(\mathrm{~m}, 8 \mathrm{H}, \mathrm{CH}_{2}\right), 2.48(\mathrm{~s}, 2 \mathrm{H}, \mathrm{CHCN}) .{ }^{31} \mathrm{P}$ $\operatorname{NMR}\left(\mathrm{CDCl}_{3}\right)$ : 76.34, 75.28 (two doublet with $J_{\mathrm{P}-\mathrm{P}}=$ $19.5 \mathrm{~Hz}) .{ }^{13} \mathrm{C} \mathrm{NMR}\left(\mathrm{CDCl}_{3}\right): 343.5\left(\mathrm{t}, J_{\mathrm{C}-\mathrm{P}}=15.0 \mathrm{~Hz}\right.$, $\left.\mathrm{C}_{\alpha}\right), 131.5-129.3(\mathrm{~m}, \mathrm{Ph}), 93.2(\mathrm{Cp}), 26.9,25.0$ $\left(\mathrm{CH}_{2} \mathrm{CH}_{2}\right), 24.3(\mathrm{CHCN})$. MS $(\mathrm{m} / \mathrm{z}): 1537.3\left(\mathrm{M}^{+}-\right.$ $\left.\mathrm{I}_{5}\right), 1409.4\left(\mathrm{M}^{+}+1-2 \mathrm{I}_{3}\right), 565.3\left(\mathrm{Cp}(\mathrm{dppe}) \mathrm{Ru}^{+}\right)$.

\section{9. $X$-ray analysis of $\mathbf{2}, \mathbf{3}, \mathbf{6}$, and $\mathbf{7 b}$}

Single crystals of 2 suitable for an X-ray diffraction study were grown as mentioned above. A single crystal of dimensions $0.20 \times 0.30 \times 0.50 \mathrm{~mm}^{3}$ was glued to a glass fiber and mounted on an Enraf-Nonius CAD4 diffractometer. Initial lattice parameters were determined from a least-squares fit to 25 accurately centered reflections. Cell constants and other pertinent data are collected in Table 1. Data were collected using the $\theta / 2 \theta$ scan method. The final scan speed for each reflection was determined from the net intensity gathered during an initial prescan and ranged from 2 to $7^{\circ}$ $\min ^{-1}$. The scan angle was determined for each reflection according to the equation $0.8+0.35 \times \tan \theta$.

The raw intensity data were converted to structure factor amplitudes and their esd's by correction for scan speed, background and Lorentz, polarization effects. An empirical correction for absorption based on the azimuthal scan, was applied to the data set. Crystallographic computations were carried out on a Microvax III computer using the NRCC structure determination package [40]. Merging of equivalent and duplicate reflections gave a total of 4597 unique measured data from which 2839 were considered observed, $I>2.0$ $\sigma(I)$. The structure was first solved by using the heavy atom method (Patterson synthesis) which revealed the position of metal, then refined via standard least-squares and difference Fourier techniques. The quantity minimized by the least squares program was $\mathrm{w}\left(\left|F_{\mathrm{o}}\right|-\left|F_{\mathrm{c}}\right|\right)^{2}$. The analytical forms of the scattering factor tables for the neutral atoms were used [41]. All other non-hydrogen atoms were refined by using anisotropic thermal parameters. Hydrogen atoms were included in the structure factor calculations in their expected positions on the basis of idealized bonding geometry but were not refined in least squares. Final refinement using full-matrix, least squares converged smoothly to values of $R=0.039$ and $R_{w}=0.038$. Final values of all refined atomic positional parameters (with esd's) and tables of thermal parameters, and structure factors are given in the supporting information. 
The procedures for $\mathbf{3}, \mathbf{6}$, and $\mathbf{7 b}$ were similar. The final residues of the refinement were $R=0.054, R_{w}=$ 0.064 for $3 ; R=0.049, R_{w}=0.056$ for $\mathbf{6}$; and $R=$ $0.053, R_{w}=0.050$ for $7 \mathbf{b}$. Final values of all refined atomic positional parameters (with esd's) and tables of thermal parameters and structure factors are given in the supporting information.

\subsection{Supporting information available}

Details of the structural determination for complexes $\mathbf{2}, \mathbf{3}, \mathbf{6}$, and $\mathbf{7 b}$ including tables of crystal data and structure refinement, positional and anisotropic thermal parameters and listings of bond distances and angles (21 pages).

\section{Acknowledgements}

We are grateful for support of this work by the National Science Council, Taiwan, the Republic of China.

\section{References}

[1] P.C. Ting, Y.C. Lin, G.H. Lee, M.C. Cheng, Y. Wang, J. Am. Chem. Soc. 118 (1996) 6433.

[2] M.I. Bruce, N.J. Windsor, Aust. J. Chem. 30 (1977) 1602.

[3] G.S. Ashby, M.I. Bruce, I.B. Tomkons, R.C. Wallis, Aust. J. Chem. 32 (1979) 1003.

[4] M. Bressan, P. Rigo, Inorg. Chem. 14 (1975) 2286.

[5] M.I. Bruce, M.G. Humphrey, Aust. J. Chem. 42 (1989) 1067.

[6] D.L. Allen, V.C. Gibson, M.L. Green, T.F. Skinner, J. Bashikin, P.D. Grebenik, J. Chem. Soc., Chem. Commun. (1985) 895.

[7] G. Consiglio, F. Morandini, Chem. Rev. 87 (1987) 761.

[8] M.I. Bruce, A.G. Swincer, Aust. J. Chem. 33 (1980) 1471.

[9] C. Löwe, V. Shklover, H.W. Bosch, H. Berke, Chem. Ber. 12 (1993) 1769.

[10] R. Gompper, E. Bartmann, Angew. Chem., Int. Ed. Engl. 17 (1978) 456

[11] D.M. DeSimone, P.J. Desrosiers, R.P. Hughes, J. Am. Chem. Soc. 104 (1982) 4842.

[12] R.P. Hughes, W.A. Donaldson, J. Am. Chem. Soc. 104 (1982) 4846.

[13] R. Weiss, C. Priesner, Angew. Chem., Int. Ed. Engl. 17 (1978) 457.
[14] R. Gompper, E. Bartmann, Angew. Chem., Int. Ed. Engl. 24 (1985) 209.

[15] U. Kirchgassner, H. Piana, U. Schubert, J. Am. Chem. Soc. 113 (1991) 2228.

[16] S. Miki, T. Ohno, H. Iwasaki, Z.I. Yoshida, J. Phys. Org. Chem. 1 (1988) 333.

[17] Z.I. Yoshida, Pure Appl. Chem. 54 (1982) 1059.

[18] R.R. Schrock, Acc. Chem. Res. 19 (1986) 342.

[19] R.P. Hughes, J.W. Reisch, A.L. Rheingold, Organometallics 4 (1985) 1754.

[20] R.P. Hughes, W. Kläui, J.W. Reisch, A. Müller, A.L. Rheingold, Organometallics 4 (1985) 1761.

[21] C. Mealli, S. Midollini, S. Moneti, L. Sacconi, J. Silvestre, T.A. Albright, J. Am. Chem. Soc. 104 (1982) 59.

[22] R.D. Adams, A. Davison, J.P. Selegue, J. Am. Chem. Soc. 101 (1979) 7232.

[23] A. Padwa, T.J. Blocklock, D. Getman, N. Hatanaka, R. Loza, J. Org. Chem. 43 (1978) 1481.

[24] A. Rabier, N. Lugan, R. Mathieu, G.L. Geoffroy, Organometallics 13 (1994) 4676.

[25] A. Antinolo, A. Otero, M. Fajardo, C. Garcia-Yebra, R. GilSanz, C. Lopez-Mardomingo, A. Martin, P. Gomez-Sal, Organometallics 13 (1994) 4679.

[26] R.S. Lyer, J.P. Selegue, J. Am. Chem. Soc. 109 (1987) 910.

[27] N. Le Narvor, L. Toupet, C. Lapinte, J. Am. Chem. Soc. 117 (1995) 7129.

[28] N.G. Connelly, M.P. Gamasa, J. Gimeno, C. Lapinte, E. Lastra, J.P. Maher, N. Le Narvor, A.L. Rieger, P.H. Rieger, J. Chem. Soc., Dalton Trans. (1993) 2575.

[29] K. Holtzhauer, C. Cometta-Morini, J.F.M. Oth, J. Phys. Org. Chem. 3 (1990) 219.

[30] D.P. Curran, C.M. Seong, Tetrahedron 48 (1992) 2175.

[31] M.I. Bruce, G.A. Koutsantonis, Aust. J. Chem. 44 (1991) 207.

[32] K.Y. Shih, R.R. Schrock, R. Kempe, J. Am. Chem. Soc. 116 (1994) 8804.

[33] W.T. Evans, R.A. Keyer, J.W. Ziller, Organometallics 12 (1993) 2618.

[34] D. Shutowski, G.D. Stucky, J. Am. Chem. Soc. 98 (1976) 1376.

[35] S.G. Feng, P.S. White, J.L. Templeton, J. Am. Chem. Soc. 116 (1994) 8613.

[36] P.A. Finn, M.S. King, P.A. Kilty, R.E. McCarley, J. Am. Chem. Soc. 97 (1975) 220.

[37] F.A. Cotton, T.W. Hall, Inorg. Chem. 17 (1978) 3525.

[38] E.J. Roskamp, S.F. Pedersen, J. Am. Chem. Soc. 109 (1987) 3152.

[39] M.I. Bruce, M.G. Humphrey, Aust. J. Chem. 42 (1989) 1067.

[40] E.J. Gabe, F.L. Lee, Y. Lepage, in: G.M. Sheldrick, C. Kruger, R. Goddard (Eds.), Crystallographic Computing 3, Clarendon Press, Oxford, UK, 1985, p. 167.

[41] International Tables for X-ray Crystallography, Vol. 4, Reidel Publishing, Dordrecht, Boston (1974). 